\title{
Review \\ Therapeutic Properties of Mesenchymal Stromal/Stem Cells: The Need of Cell Priming for Cell-Free Therapies in Regenerative Medicine
}

\author{
Vitale Miceli *(D), Matteo Bulati, Gioacchin Iannolo (D), Giovanni Zito, Alessia Gallo and Pier Giulio Conaldi
}

check for updates

Citation: Miceli, V.; Bulati, M.; Iannolo, G.; Zito, G.; Gallo, A.; Conaldi, P.G. Therapeutic Properties of Mesenchymal Stromal/Stem Cells The Need of Cell Priming for Cell-Free Therapies in Regenerative Medicine. Int. J. Mol. Sci. 2021, 22,

763. https://doi.org/10.3390/ ijms22020763

Received: 22 December 2020 Accepted: 12 January 2021 Published: 14 January 2021

Publisher's Note: MDPI stays neutral with regard to jurisdictional clai$\mathrm{ms}$ in published maps and institutional affiliations.

Copyright: $(\odot 2021$ by the authors. Licensee MDPI, Basel, Switzerland. This article is an open access article distributed under the terms and conditions of the Creative Commons Attribution (CC BY) license (https:// creativecommons.org/licenses/by/ $4.0 /)$.
Research Department, IRCCS ISMETT (Istituto Mediterraneo per i Trapianti e Terapie ad alta Specializzazione), 90127 Palermo, Italy; mbulati@ismett.edu (M.B.); giannolo@ismett.edu (G.I.); gzito@ismett.edu (G.Z.); agallo@ismett.edu (A.G.); pgconaldi@ismett.edu (P.G.C.)

* Correspondence: vmiceli@ismett.edu; Tel.: +39-091-21-92-649
Abstract: Mesenchymal stromal/stem cells (MSCs) are multipotent adult stem cells that support homeostasis during tissue regeneration. In the last decade, cell therapies based on the use of MSCs have emerged as a promising strategy in the field of regenerative medicine. Although these cells possess robust therapeutic properties that can be applied in the treatment of different diseases, variables in preclinical and clinical trials lead to inconsistent outcomes. MSC therapeutic effects result from the secretion of bioactive molecules affected by either local microenvironment or MSC culture conditions. Hence, MSC paracrine action is currently being explored in several clinical settings either using a conditioned medium (CM) or MSC-derived exosomes (EXOs), where these products modulate tissue responses in different types of injuries. In this scenario, MSC paracrine mechanisms provide a promising framework for enhancing MSC therapeutic benefits, where the composition of secretome can be modulated by priming of the MSCs. In this review, we examine the literature on the priming of MSCs as a tool to enhance their therapeutic properties applicable to the main processes involved in tissue regeneration, including the reduction of fibrosis, the immunomodulation, the stimulation of angiogenesis, and the stimulation of resident progenitor cells, thereby providing new insights for the therapeutic use of MSCs-derived products.

Keywords: Mesenchymal stromal/stem cells; priming; paracrine mechanism; cell-free therapies; regenerative medicine

\section{Introduction}

Mesenchymal stromal/stem cells (MSCs) belong to the pool of adult stem cells that, in a specific microenvironment termed the "stem cells niche", support tissue regeneration in both physiologic and pathologic conditions contributing to tissue homeostasis [1-3]. These cells can increase their own compound [4] and replace individual components of the microenvironment by differentiating or attracting supporting cells to a niche [1-3]. It has been shown that in tissues such as intestine and skin, MSCs support a high cellular turnover [5,6]. In contrast, in other tissues such as skeletal muscle, MSCs are considered adult stem cells that support regeneration after injury, even if they marginally contribute to myofiber renewal during physiologic turnover [7]. Indeed, MSC-like cells with adipogenic phenotype resident in the muscles are quiescent in intact tissue, but get activated in injured ones, providing a momentary source of key factors that induce proliferation of myogenic progenitor cells. Thus, these MSCs that normally have adipogenic potential, when injuryactivated, can stimulate the differentiation of the myogenic progenitor's cells supporting tissue repair [3,8]. A similar phenomenon has been shown in skin tissue, where MSC-like adipose precursor cells within the skin appear to be crucial for epithelial cell regulation [9]. Therefore, MSCs can be considered as key regulatory components in the regenerating stem cell niche (Figure 1). 


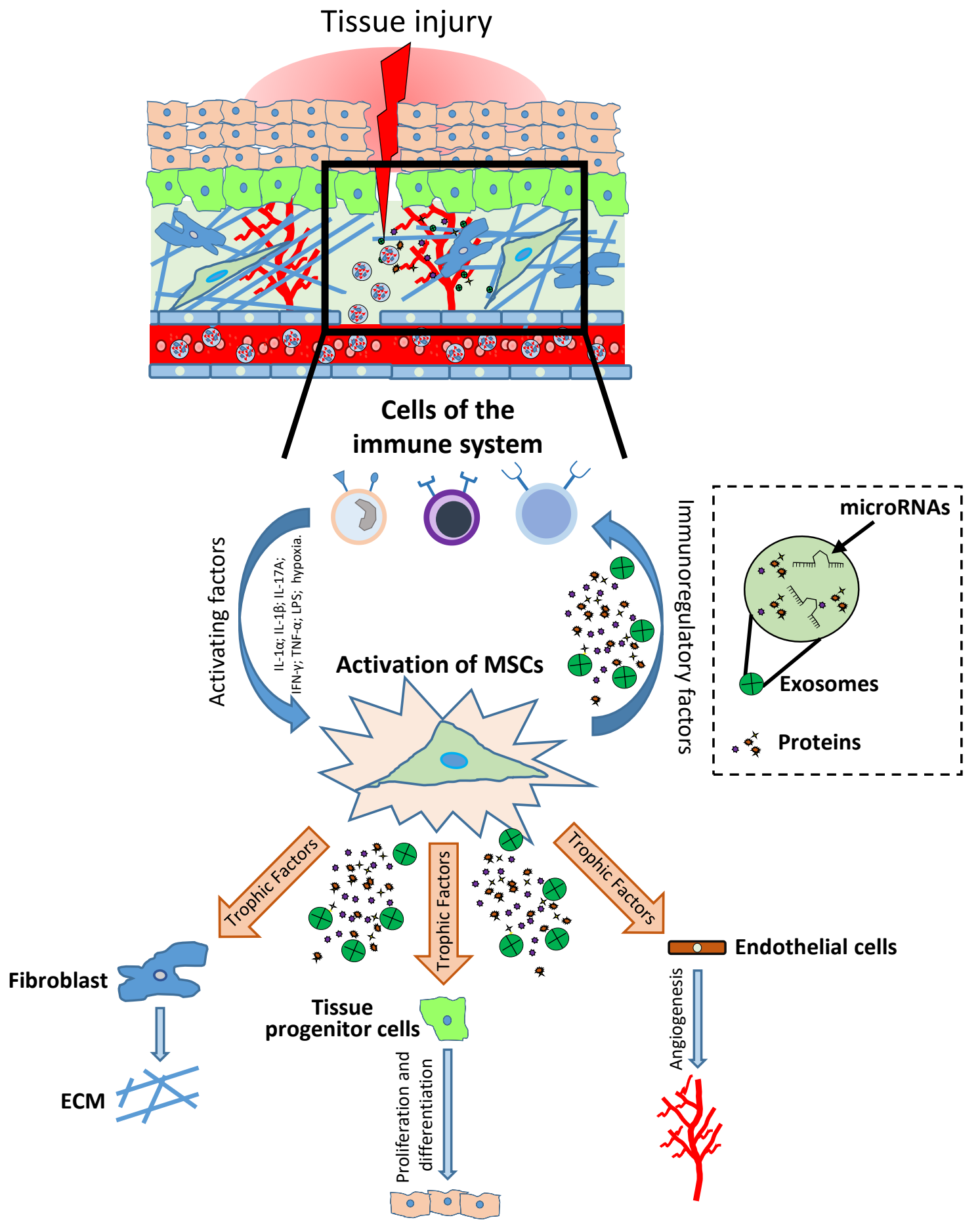

Figure 1. Role of mesenchymal stromal/stem cells (MSCs) in tissue injury and repair. After injury, the damaged tissue activates MSCs through different inflammatory signals (IL- $1 \beta$, IFN- $\gamma$, TNF- $\alpha$, LPS; hypoxia). MSC activation leads to coordination of the microenvironment by both the production of immunomodulatory factors (to modulate the progression of inflammation) and the production of growth factors which subsequently stimulate endothelial cells, fibroblasts cells and tissue progenitor cells. The physiological and orderly action of these factors allows tissue repair through angiogenesis, remodeling of the extracellular matrix (ECM) and functional tissue restoration through tissue progenitor cells differentiation.

These findings provide a robust rationale to investigate the role of MSCs as a therapeutic product to support tissue injury responses in different diseases. MSCs are multipotent cells with easy accessibility, few ethics-related issues, and higher adaptability to in vitro cultures for expansion. Unlike pluripotent stem cells, multipotent MSCs have a limited self-renewal capacity [10]. In light of this, in recent years the "stem" cell definition has 
been changed to "stromal" in order to give a more appropriate connotation to describe MSCs. Furthermore, these cells are immuno-privileged due to their low expression of CD40, CD80, CD86 and major histocompatibility complex I (MHC I), as well as the lack of $M H C$ II expression [11-14]. These features make these cells a very useful tool for cell therapy in the field of regenerative medicine.

MSCs are found in several tissues, including bone marrow (BM) [15], adipose tissue (AT) [16], umbilical cord (UC) [17], dental pulp [18] and placenta [19], where these cells are surrounded by different cell types such as immune cells, epithelial cells, endothelial cells and stromal cells, and can exhibit immunomodulatory [20,21], angiogenic [22,23] and anti-oxidative properties [24]. Over the past decade the therapeutic action of MSCs has been investigated in several clinical trials for the treatment of many disorders including cardiovascular, neurodegenerative, immune, lung, liver, kidney and orthopedics diseases (clinicaltrials.gov). In these cases, MSCs have been shown to have moderate or poor efficacy, and the results from different clinical trials are controversial [25-29], indicating an urgent need to optimize the therapeutic use of MSCs or to enhance MSC potency. This inconsistent evidence is potentially related both to intrinsic differences in the use of cellbased products and to the lack of standardized methods for MSC production that affects their potency. MSC effects depend both on tissue source [30,31] and on how they are produced and administered. Indeed, it has been shown that the composition of MSCs secretome can be modulated by preconditioning of MSCs with hypoxia and cytokines treatments, as well as the growing of MSCs under specific culture systems, including threedimensional (3D) culture conditions [32-35]. In response to MSC "priming", the production of factors is switched towards an anti-inflammatory and pro-trophic phenotype that results in a homeostatic regulation of tissue regeneration/repair [36,37]. Currently, it is often stated that the efficacy of MSCs therapies is probably not related to cell engraftment and replacement but is linked to the production of crucial paracrine factors, such as cytokines, growth factors, and exosomes (EXOs), that regulate the cell niche for their regeneration. Indeed, in response to specific stimuli, MSCs are activated and can secrete a plethora of regulating factors that affect tissue injury responses in a transitory and paracrine manner to orchestrate the repairing tissue processes [20,38-44]. In a different model of injury it has been shown that MSCs, mainly triggered by inflammation processes, induce tissue regeneration/repair by cell niche empowerment/regulation [45-47]. In these cases, in an inflammatory-injured tissue, MSC effects were mediated by paracrine mechanisms that lead to regulation of fibrosis, immunomodulation, stimulation of angiogenesis and stimulation of resident cells to coordinate both tissue regeneration and function recovery [37,48-52]. Therefore, due to the regenerative potential and trophic properties of specific MSC-derived products, such as the conditioned medium (CM) and EXOs, these products have emerged as possible therapeutic tools with numerous applications and are consequently being extensively evaluated for medical use [53-55]. In addition, the clinical application of MSCderived products must be considered for their advantages as opposed both to the lack of safety in the long-term use of MSCs and the risks related to transmission of infection diseases, such as some viruses found in the transplanted allogenic cells.

In order to make the clinical application of MSC-derived products advanced in the field of regenerative medicine, the first point is to optimize the therapeutic strategies by the identification of the best way to prime MSCs and to improve their regenerative properties. This review focuses on promising cell priming methods that enhance paracrine therapeutic properties of MSCs in the main processes of tissue regeneration, such as angiogenesis, immunomodulation, fibrosis and stimulation of tissue resident cells.

\section{Main MSC Priming Strategies to Enhance the Production of Key Factors that Stimulate Resident Cells for Tissue Regeneration/Repair}

As mentioned above, MSC preconditioning has been considered an important tool to improve the effects of MSCs in regeneration and repair of injured tissues. The different priming strategies have been implemented according to the cell types that needed to be targeted in the injured tissues. Indeed, while the priming of MSCs with pro-inflammatory 
cytokine and 3D cultures has been mainly tested to modulate the inflammation and stimulate the angiogenesis in injured tissues, hypoxia has been applied as the major priming method of MSCs in order to enrich their CM with soluble factors involved in the stimulation of resident cells, such as parenchymal and tissue-specific stem cells. Thus, in the following paragraph we will focus our attention on the literature defining the role of preconditioned MSCs and the identified soluble factors which were associated with the stimulation of tissue-specific resident cells.

It has been shown that in hypoxia conditions MSCs up-regulated several factors that contributed to hepatocyte proliferation in vitro and liver regeneration in vivo in hepatectomized mice [56]. In this work, Lee and collaborators demonstrated that the MSC-derived $\mathrm{CM}$ was enriched in factors including interleukin 6 (IL-6), tumor necrosis factor alpha (TNF- $\alpha$ ), hepatocyte growth factor (HGF) and vascular endothelial growth factor (VEGF), and this secretome was able to increase proliferating cell nuclear antigen (PCNA) and Ki67 expression as well as markers of liver regeneration, such as signal transducers and activators of transcription 3 (pSTAT3), and down-regulation of suppressor of cytokine signaling 3 (SOCS3) [56]. Similarly, Yu and colleagues showed that the CM derived from hypoxiainduced MSCs promoted liver regeneration through VEGF signaling [57]. Another study from Leroux and co-workers showed that hypoxia preconditioning of MSCs improved the survival of engrafted MSCs in a mouse hindlimb ischemia model. Furthermore, the authors clearly showed that hypoxic MSCs, among others, stimulated the differentiation of resident myoblast via Wnt4 soluble factor release in a paracrine manner [58]. Recently, in an in vivo model of myocardial infarction, $\mathrm{Hu}$ and co-workers demonstrated that hypoxia preconditioned MSCs inhibited cardiac apoptosis and stimulated cardiomyocytes proliferation [59]. Furthermore, it has been shown that EXOs from hypoxic MSCs were enriched in miR-26a which, in turn, activated Wnt signaling to promote cardiomyocyte survival in a rat model of cardiac ischemia-reperfusion [60].

Hypoxia priming of MSCs has been shown to promote neurogenesis in a rat model of traumatic brain injury. In particular, Chang and colleagues demonstrated that the $\mathrm{CM}$ derived from hypoxia-treated MSCs was enriched in soluble factors including HGF and VEGF which, in turn, stimulated the proliferation of neuronal cells in rat peri-ischemic brain regions [61]. However, the author speculated that other undefined soluble factors in the hypoxic preconditioned MSC CM might be involved in the rescue of the neural phenotype. In a similar manner, it has recently been demonstrated that hypoxic MSCs enhanced axonal survival compared to normoxia culture conditions in a rat model of spinal cord injury [62].

The role of MSC priming with regard to pro-inflammatory cytokine has also been explored in the tissue regeneration. Indeed, as inflammation normally occurs after bone injury, it has been suggested that cytokine treatment might stimulate stem cell osteogenic differentiation. For instance, tumor necrosis factor alpha (TNF- $\alpha$ )-preconditioned CM from MSCs has been shown to improve bone regeneration in vitro by up-regulating bone morphogenetic protein 2 (BMP2) and thus stimulating cell proliferation and the expression of differentiation markers, such as runt-related transcription factor 2 (Runx2) and Collagen I [63]. Furthermore, the authors clearly demonstrated that the above described effects were associated with EXOs contained in the CM. In particular, TNF- $\alpha$ preconditioning stimulated MSCs to increase Wnt3a levels in the EXOs that, in turn, further improved cell proliferation and bone differentiation when compared to $\mathrm{CM}$ from unconditioned MSCs [64]. Regenerative properties of MSCs on bone were also shown by Novais et al. who demonstrated that both basic fibroblast growth factor (bFGF) and hypoxic priming improved MSCs proliferation and osteogenic differentiation resulting in the repair of critical size calvarial bone defects created in nude mice [65].

The priming of MSCs with small molecules also represents a promising therapeutic strategy for the treatment of neurodegenerative diseases. Indeed, the preconditioning of MSCs with cyclic AMP (cAMP), bFGF, platelet-derived growth factor (PDGF) and Heregulin $\beta 1$ stimulates MSCs to secrete different neurotrophic factors (NTF), includ- 
ing glial-derived neurotrophic factor (GDNF), brain-derived neurotrophic factor (BDNF), VEGF and HGF [66]. In vivo studies showed that MSCs secreting NTF have protective effects in several animal models of neurodegenerative diseases, such as Parkinson's disease, multiple sclerosis and Huntington's disease [67-69], where, after MSCs administration, marked improvements of diseases were shown. Moreover, Linares et al. showed that preconditioning of MSCs with lithium and valproic acid (VPA) exerted neuroprotective effects. Actually, in transgenic mice with Huntington's disease, primed MSCs administered intranasally migrated into the brain, improving motor and behavior performance, decreasing neuronal death and reducing huntingtin aggregates in the striatum [70].

In the field of regenerative medicine, a critical discussion is focused on the the fact that endogenous MSCs undergo senescence, with consequent reduction of the immunomodulatory and wound-healing properties of those cells [71,72]. These aging-related declines can be attributed to the intrinsic aging of stem cells [73] as well as to aging-related modifications of both the extracellular matrix and stem cell niche [74,75]. Overall, these tissue alterations reduce MSC self-renewal, maintenance and regenerative potential, and these dysfunctional processes have been implicated in frailty syndrome [76], which is characterized by declines in both health and function of organs/tissues. To date, there is no specific therapy available to prevent or treat frailty syndrome and, in this respect, MSCs could represent a potential tool to ameliorate or improve frailty. MSC treatments are safe in older/frail patients [77,78], where pro-inflammatory cytokines such as TNF- $\alpha$, IL-6 and C-reactive protein (CRP) increased during aging [76]. Interestingly, it has been shown that, in an inflammatory environment typical of frailty patients, MSCs were primed to show anti-aging effects because they are able to reduce the expression of pro-inflammatory cytokines [79,80]. Moreover, some clinical trials (e.g., NCT02065245 and NCT04174898) investigated the safety and efficacy of intravenous infusion of MSCs as an innovative therapy for treating frailty patients and, in this setting, also testing the infusion of preconditioned MSCs to obtain superior results could be greatly interesting.

On the whole, these studies clearly suggest the importance of preconditioning MSCs in improving their impact on organ/tissue regeneration and repair. However, up to now little information has been available on the effects of preconditioned MSCs on parenchymal and tissue stem cells. We are still far from a clear understanding of the underlying molecular mechanisms, so it is now crucial to better define the paracrine factors released by MSCs that mediate the effects on proliferation and differentiation of tissue resident cells.

\section{Main MSC Priming Strategies to Enhance the Production of Angiogenic Factors}

MSCs became very appealing because of the clinical promise for tissue repair in regenerative medicine [52] and, for that reason, they are used in a high number of clinical trials [28]. The therapeutic benefits of MSCs have also been referred to the large number of molecules they secrete in response to specific stimuli, which then exert paracrine effects upon neighboring cells and tissues [81]. Among the therapeutic properties of MSCs, the angiogenic ones have been extensively studied because of their significance in many pathological conditions such as myocardial infarction, brain injury and limb ischemia $[31,56,57]$. The totality of soluble factors, mostly growth factors and cytokines, and including a vesicular component (including EXOs) carrying proteins, lipids and genetic material [82], is known as the secretome [83] and is considered to be responsible for the paracrine effects of MSCs on tissue regeneration processes including angiogenesis.

It has been postulated that the angiogenic potential of MSCs differs as a consequence of their original tissue (Wharton's Jelly (WJ), AT and BM) due to the composition and concentration of angiogenic factors [30]. However, there are conflicting studies arguing that different sources of MSCs show different angiogenic effect. Previously, it has been reported that the AT-MSCs produce a higher expression of the angiogenic factors such as VEGF, insulin-like growth factor 1 (IGF-1) and IL-8, as well as matrix metalloproteinase-3 (MMP3) and MMP9, thus showing a greater angiogenic potential compared to BM-MSCs [84]. In contrast, a study published in 2019 on a proteomic analysis among different MSC 
secretomes assessed that BM-MSC ' $\mathrm{CM}$ and WJ-MSCs' $\mathrm{CM}$ retained higher angiogenic profiles when compared with the AT-MSCs' CM because of higher expression of AKT serine/threonine kinase 1 (AKT1) and $b F G F$ [85]. The fact that the paracrine activity is not consistent across different samples may be explained by the different sources (neonatal versus adult) and by a lack of standardization of culturing techniques. To solve these problems, in recent years, priming approaches to activate and generate MSC products with improved potential for different clinical applications have been investigated.

Among the soluble factors with angiogenic potential, MSCs secrete high levels of VEGF, transforming growth factor beta (TGF- $\beta$ ), HGF, IL-8, bFGF, monocyte chemoattractant protein 1 (MCP-1) and IL-6, as well as a lot of microvesicles carrying non-coding RNAs (ncRNAs) such as microRNAs (miRNAs) with angiogenic function [86,87]. Considering the in vivo MSC niche conditions that occur during tissue injury, hypoxia priming has been used as the main priming strategy to lead MSCs towards a pro-angiogenic phenotype [88-96].

Gorin et al. proved that bFGF and/or hypoxia can be considered as priming treatments capable of enhancing VEGF release and improving the angiogenic potential of MSCs [97]. Moreover, hypoxia-primed MSCs up-regulated VEGF and enhanced significantly angiogenesis when injected into the pulp cavities of rabbit molars [98]. Leroux et al. demonstrated that MSCs cultured under hypoxic conditions had increased high angiogenic and regenerative potentials via a paracrine wnt-dependent mechanism [58] and Xue et al. demonstrated that, in MSCs, hypoxia enhanced angiogenetic potential up-regulated the VEGF and protein kinase A (PKA) signaling pathway [99]. MSCs primed with hypoxia also showed increased expression of adhesion molecules, including fibronectin 1, E-cadherin, $\mathrm{N}$-cadherin and integrins, crucial proteins for angiogenesis processes [100]. Moreover, hypoxic preconditioning increased MSC angiogenic properties via the HIF- $1 \alpha$-GRP78-Akt axis and an increased secretion of aforementioned factors such as VEGF, HGF and bFGF in a murine model of hindlimb ischemia [101]. Hypoxic priming increases hypoxia-inducible factor 1-alpha (HIF-1 $\alpha$ ) in MSCs that produce a conditioned medium enriched by VEGF that lead to migration and tube formation from HUVECs [102].

Interestingly, Han et al. showed that hypoxia treatment enhances MSC survival and their angiogenic properties through unusual mechanisms. In particular, the authors demonstrated that hypoxia preconditioning induced up-regulation of cellular prion protein $\left(\operatorname{PrP}^{\mathrm{C}}\right)$, which, in turn, enhanced MSCs proliferation via $\operatorname{PrP}^{\mathrm{C}}$-dependent JAK2/STAT3 activation and inhibited oxidative stress-induced apoptosis via $\mathrm{PrP}^{\mathrm{C}}$-dependent inactivation of cleaved caspase-3. Moreover, when those cells were administered to a murine hindlimb ischemia model, an improvement of functional recovery of the ischemic tissue and neovascularization were observed, and the levels of epidermal growth factor (EGF), VEGF, FGF and HGF were significantly higher in ischemic tissue treated with primed MSCs compared to control group [103].

As described above, secreted EXOs are another angiogenic action mechanism of MSCs [96,104] acting as cargo of miRNAs [105]. The importance of miRNAs as regulators for translation, RNA splicing and gene expression rely on the impact they can exert on host pathways [106]. Kane et al. in 2014 indicated miRNAs as being important regulators of angiogenesis [107] and many studies are related to the presence of miRNAs in MSCs' secretome. Krawczenko et al. have recently demonstrated that four pro-angiogenic miRNAs, miR-126, miR-296, miR-378 and miR-210, were found to be highly expressed in microvescicles from MSCs, while there was a low expression of anti-angiogenic miRNAs such as miR-221, miR-222 and miR-92a [86]. Interestingly, in MSCs, hypoxia preconditioning induced up-regulation of miR-675 and subsequent angiogenic response by decreasing HIF- $1 \alpha$ negative regulators and increasing VEGF secretion and VEGF receptor 1 expression [108]. Gonzalez-King and colleagues showed that MSCs overexpressing HIF- $1 \alpha$ secrete higher amounts of EXOs compared to control MSCs, and these EXOs had increased angiogenic capacity and overexpressed different miRNAs implicated in angiogenesis processes, including miR-15, miR-16, miR-17, miR-31, miR-126, miR-145, miR-320a and miR-424 [109]. Furthermore, Zhu et al. demonstrated that hypoxia priming of MSCs induced the produc- 
tion of angiogenic EXOs that improved cardiac repair through miR-125 in a mice model of myocardial infarction [110]. There is very little information about MSC-derived ncRNAs modulating angiogenesis, and the strategy of priming MSCs to modulate functional ncRNAs to improve angiogenic potential of MSCs is very attractive.

\section{Main MSC Priming Strategies to Enhance the Production of Immunomodulatory Factors}

MSCs can modulate the functions of all immune cells, including $\mathrm{T}$ and B lymphocytes, natural killer cells, monocyte/macrophages, dendritic cells and neutrophils [111]. T and B cells, activated to execute their effector functions, are the primary mediators of different inflammatory and autoimmune diseases as well as being active in transplant rejection mechanisms and graft-versus-host disease [112]. In this context, MSCs exert a regulatory function on both T and B lymphocytes [113,114]. Concerning inflammatory cells, MSCs can reduce, or even inhibit neutrophils and macrophages infiltration [115], attenuate the cytotoxic activity of NK cells [116], inhibit the differentiation of dendritic cells [117] and induce the switch of monocytes from the pro-inflammatory M1 phenotype to an antiinflammatory M2 phenotype [20].

There are several pieces of evidence that show that the immunomodulatory effects of MSCs may be mediated by paracrine factors, rather than a direct cellular action $[86,92,93]$, and that the anti-inflammatory properties of MSCs can be enhanced to promote the efficacy of immunomodulation as a therapeutic strategy in the field of regenerative medicine.

The finest way of optimizing MSC action is their preconditioning (MSC priming), by which MSCs increase their survival rate and enhance their secretory activity [118]. The most commonly used way to prime MSCs for the improvement of immunomodulatory functions is their pre-activation with cytokines. MSCs primed with a variety of cytokines are enabled to produce different functional factors which exert specific immunomodulatory effects.

It has been shown that, using IL-17, MSCs increase the production of IL-6, which suppress $\mathrm{T}$ cell proliferation and inhibits Th1 cytokines production [119]. Instead, when primed with interferon gamma (IFN- $\gamma$ ), MSCs mainly produce indoleamide 2,3-dioxygenase (IDO) (a crucial factor able to suppress lymphocytes proliferation) [120], and also secrete key regulators of immunomodulation, such as prostaglandin E2 (PGE2), HGF, TGF- $\beta$ and MCP-1. Furthermore, an increase of $M H C I$ and II expression and of co-stimulatory molecules was also showed [121]. Interestingly, Sivanathan et al. proposed that unlike MSC-primed with IFN- $\gamma$, the priming with IL-17 enhances T cell immunosuppression but not their immunogenicity, showing no induction of MHC I/II and T cell co-stimulatory molecule CD40 [122]. In the same work, functional studies revealed that MSCs primed with IL-17 showed higher immunosuppressive potential against $\mathrm{T}$ cells proliferation not due to $I D O$, prostaglandinendoperoxide synthase 2 (COX-2) or TGF- $\beta$, but due to increased IL-6 expression [122]. Redondo-Castro et al. showed that when MSCs were primed simultaneously with IL- $1 \alpha / \beta$, TNF- $\alpha$ and IFN- $\gamma$, these cells were able to produce granulocyte colony-stimulating factor (G-CSF), a growth factor which has a strong anti-inflammatory effect on LPS-activated microglia cells [36]. English et al., simultaneously co-treating IFN- $\gamma$ and TNF- $\alpha$, induced MSCs to produce both IDO and PGE2, with the result of inhibiting in vitro the allogeneic mixed lymphocyte reaction (MLR) [123].

Preconditioned MSCs are also able to induce the polarization of monocytes towards an anti-inflammatory phenotype. Indeed, MSCs stimulated with the cocktail IFN- $\gamma /$ TNF$\alpha /$ LPS or with IFN- $\gamma /$ IL-1 $\beta$ produced respectively PGE2 [124] or IL-6 [125], and both factors were able to induce the switch of monocyte from the pro-inflammatory M1 phenotype to an anti-inflammatory M2 phenotype. The same result has been obtained by priming MSCs only with IFN- $\gamma$. In this case, these cells produced EXOs containing different miRNAs (miR-23a, miR-26b, miR-125b, miR-130b, miR-140, miR-203a, miR-223, miR-224 and miR-320a) which not only act on monocyte polarization (switch of M1 phenotype to M2 phenotype), but also on T cells anergy induction [20]. Moreover, miRNAs delivered by EXOs that have both antiseptic and M2 monocytes polarization capacities have been 
shown to be produced by different kind of MSCs primed with IL-1 $\beta$. Among these, miR-21 is produced by almost all IL-1 $\beta$-primed MSCs [126] and miR-146a from UC-MSCs [127].

Apart from cytokines priming, specific culture conditions such as 3D cultures (cells grown as spheroids) can also affect MSC immunomodulatory activity. Indeed, MSCs grown as spheroids become able to produce high levels of IDO that has a strong in vitro antiproliferative effect on T cells [128]. Moreover, placenta-derived MSC spheroids secrete high levels of PGE2, HGF and leukemia inhibitory factor (LIF) [35] which can suppress pro-inflammatory M1 macrophages inducing M2 macrophages phenotypes [129-131]. Therefore, cytokine-mediated conditioning and/or 3D culture of MSCs may be considered as useful strategies to improve immunosuppressive properties maximizing the therapeutic effects of MSCs.

\section{Main MSC Priming Strategies to Enhance the Production of Anti-Fibrotic Factors}

Organ fibrosis represents the common consequence of functional cell replacement by fibrotic tissue, resulting in the reduction of the organ performance. Fibrosis involves many organs degenerating into numerous diseases, such as liver cirrhosis, kidney and myocardial fibrosis.

MSCs have been considered as a promising tool for treatment of various disorders including fibrosis. Indeed, while inflammation and fibrosis have a very close reciprocal relationship and MSCs have a strong immunomodulatory capacity, these cells appear to be tools capable of regulating fibrosis in many compartments.

The paracrine effect of MSCs in cardiac fibrosis was observed more than a decade ago, in a study in which MSC antifibrotic properties were linked to the regulation of matrix metalloproteinases (MMPs) [132]. In this work, Mias et al. showed that, in a rat model, MSC injection significantly improved morphological and functional cardiac parameters after myocardial infarction (MI). In particular, they demonstrated that CM from MSCs reduced the collagen secretion and increases the activity of MMP2 and MMP9 in cardiac fibroblasts. These processes prevent fibrosis by reducing collagen accumulation and consequently the fibrotic deposition of the extracellular matrix [132]. MSC effects have been also evaluated in a rat model of diabetic cardiomyopathy, in which uncontrolled diabetes was characterized by a long-term complication leading to myocardial fibrosis [133]. In this work, starting from the observation that PGE2 is secreted by MSCs during inflammation and immune response, the authors demonstrated the key role of this factor in fibrosis by using PGE2-deficient MSCs.

Interestingly, many MSCs priming methods, such as treatment with IFN- $\gamma[20,121]$, IL-17 [122], TNF- $\alpha$ [134] and the growth of MSCs as spheroids [35,135], are able to upregulate both MMPs and PGE2. Furthermore, different studies are evaluating hypoxia as a priming strategy to improve MSC potential in fibrosis inhibition [136]. In particular, a recent work in a mouse model of liver fibrosis demonstrated that hypoxia-primed MSCs (H-MSCs) enhanced PGE2 expression [137]. They also showed increased levels of miR-210 in H-MSCs and this miRNA played different roles in fibrosis processes such as suppression of apoptosis, arrest of cell proliferation and repression of mitochondria respiration [137].

In an injured liver tissue, several pro-fibrotic factors such as TGF- $\beta$, PDGF and IL-4 are secreted by resident tissue cells or immune cells, playing a crucial role in the activation of hepatic stellate cells (HSCs), which are important for the production of extracellular matrix in the liver [138]. Moreover, macrophages also play a central role in liver fibrosis, in which during hepatic fibrogenesis, pro-inflammatory M1 macrophages secrete profibrogenic factors such as TGF- $\beta$, PDGF and MCP-1 $[139,140]$. In the liver, antifibrotic activities of MSCs were attributed to either direct or indirect effects on HSCs. Indeed, MSCs can migrate towards liver injured sites where they are exposed to inflammatory cytokines and secrete many paracrine factors (e.g., PGE2, IDO, IL-6, IL-10), including EXOs, resulting in the suppression of immune cells that are responsible for the fibrosis process $[141,142]$. In this regard, it has been shown that MSCs primed with IFN- $\gamma$ increased their production of PGE2, IDO, IL-6 and IL-10 and produced EXOs containing specific miRNAs capable of inducing immunomodulation by inhibiting PBMC proliferation and 
inducing the macrophage M2 phenotype [20]. Therefore, although it has not been proven yet, MSC priming with INF- $\gamma$ could represent a very important strategy to enhance the therapeutic antifibrotic potential of MSCs in liver fibrosis.

Otherwise, genetic engineering has been used to potentiate the antifibrotic activity of MSCs. In particular, MSC-derived EXOs loaded with miR-19 have been used in MI mouse models [143]. This miRNA has been demonstrated to reduce cardiac fibrosis and enhance the recovery of cardiac function in mouse models [144]. In this way, priming methods such as hypoxic treatment have also been used to induce miR-125 expression in MSCderived EXOs [110]. In particular, normoxia-conditioned MSC-derived EXOs (N-EXOs) and hypoxia-EXOs (H-EXOs) have been tested in MI mouse models. The MSC H-EXOs have an enhanced ability to recover the cardiac function when compared to N-EXOs and this gain of function was ascribed to the presence of EXO-derived miR-125. Indeed, after miRNA silencing $(\mathrm{KO})$, the mice treated with mi-R $125^{\mathrm{ko}}-\mathrm{H}-\mathrm{EXO}$ s showed an increase in the fibrotic area of the MI compared to normal H-EXOs EXOs [110]. The antifibrotic action of this miRNA has also been demonstrated in the liver where miR-125 reduces liver fibrosis by increasing the autophagy [145].

In vivo, liver injured tissue promotes inflammatory processes that stimulate MSCs to release various growth factors and cytokines such as HGF, EGF, IL-6 and TNF- $\alpha$ [146], and among them, HGF plays a well-established role in liver pathogenesis by attenuating liver fibrosis in various in vivo models [147-150]. Starting from this observation, engineered MSCs overexpressing HGF have been used in a rat model of liver fibrosis. In this model, the effect of modified MSCs was clearly enhanced compared to normal MSCs, with the consequent enhancement of antifibrotic activity [151]. A similar approach was used in an MI mouse model [152] and in a radiation-induced lung injury mouse model [153]. Another group also used the gene-modified MSCs to enhance the antifibrotic activity of these cells [154]. However, the genetic engineering approach to MSCs has some counter indications because these methods require genetic modification and are therefore incompatible with clinical applications. Also many papers showed with regard to this that different priming approaches, such as 3D cultures of MSCs [35], IFN- $\gamma$ [121] and TNF- $\alpha$ [134] treatment, enhance the MSCs production of HGF, making them a potential therapeutic tool to treat liver fibrosis (Table 1). Very few studies explored the application of primed MSCs in the pathogenesis of fibrosis and this currently represents a scientific need in the field of MSC research.

Table 1. Priming treatments of MSCs and production of therapeutic factors.

\begin{tabular}{|c|c|c|c|c|c|}
\hline MSCs & Priming Treatments & MSC Product & $\begin{array}{c}\text { Functional Factors } \\
\text { Detected }\end{array}$ & Biological Effects & Reference \\
\hline AMSCs & IFN- $\gamma$ & EXOs & $\begin{array}{l}\text { miR-23a, miR-26b, } \\
\text { miR-125b, miR-130b, } \\
\text { miR-140, miR-203a, } \\
\text { miR-223, miR-224, } \\
\text { miR-320a }\end{array}$ & $\begin{array}{l}\text { Regulation of T cell } \\
\text { activation/anergy and } \\
\text { induction of M2-like } \\
\text { polarized phenotype in } \\
\text { monocytes }\end{array}$ & {$[20]$} \\
\hline AMSCs & $\begin{array}{c}\text { 3D } \\
\text { cultures/spheroids }\end{array}$ & CM EXOs & $\begin{array}{c}\text { HGF, PDGF, TGF- } \beta \text {, } \\
\text { VEGF, FGF1, GRO } \alpha, \\
\text { SDF-1, EGF, IL-6, PGE2, } \\
\text { LIF }\end{array}$ & $\begin{array}{c}\text { Increased angiogenesis and } \\
\text { inhibition of PBMC } \\
\text { proliferation }\end{array}$ & [35] \\
\hline BM-MSCs & $\begin{array}{l}\text { IL- } 1 \alpha / \beta ; \text { TNF- } \alpha ; \\
\text { IFN- } \gamma\end{array}$ & $\mathrm{CM}$ & G-CSF & $\begin{array}{c}\text { Reduction in the secretion of } \\
\text { inflammatory mediators in } \\
\text { LPS-activated microglial } \\
\text { cells }\end{array}$ & {$[36]$} \\
\hline AdMSCs & Hypoxia & $\mathrm{CM}$ & IL-6, TNF- $\alpha$, HGF, VEGF & Induced liver regeneration & [56] \\
\hline BM-MSCs & Hypoxia & $\mathrm{CM}$ & VEGF & Induced liver regeneration & [57] \\
\hline BM-MSCs & Hypoxia & $\mathrm{CM}$ & Wnt4 & $\begin{array}{l}\text { Improvement of vascular } \\
\text { and skeletal muscle fiber } \\
\text { regeneration }\end{array}$ & {$[58]$} \\
\hline
\end{tabular}


Table 1. Cont

\begin{tabular}{|c|c|c|c|c|c|}
\hline MSCs & Priming Treatments & $\begin{array}{c}\text { MSC } \\
\text { Product }\end{array}$ & $\begin{array}{l}\text { Functional Factors } \\
\text { Detected }\end{array}$ & Biological Effects & Reference \\
\hline BM-MSCs & Hypoxia & $\mathrm{CM}$ & - & $\begin{array}{l}\text { Induced cardiomyocytes } \\
\text { proliferation }\end{array}$ & [59] \\
\hline MSCs & Hypoxia & EXOs & $\operatorname{miR}-26$ & $\begin{array}{c}\text { Improvement of cardiomyocyte } \\
\text { survival }\end{array}$ & {$[60]$} \\
\hline BM-MSCs & Hypoxia & $\mathrm{CM}$ & HGF, VEGF & $\begin{array}{l}\text { Improvement of neuronal cells } \\
\text { proliferation }\end{array}$ & {$[61]$} \\
\hline UC-MSCs & Hypoxia & $\mathrm{CM}$ & HGF, BDNF, VEGF & Improvement of axonal survival & [62] \\
\hline AdMSCs & TNF- $\alpha$ & $\mathrm{CM}$ & BMP2 & $\begin{array}{l}\text { Improvement of bone } \\
\text { regeneration }\end{array}$ & {$[63]$} \\
\hline AdMSCs & TNF- $\alpha$ & EXOs & Wnt3a & $\begin{array}{l}\text { Promoted the proliferation and } \\
\text { osteogenic differentiation of } \\
\text { primary osteoblastic cells }\end{array}$ & {$[64]$} \\
\hline DP-MSCs & bFGF; Hypoxia & $\mathrm{CM}$ & - & Improvement of bone formation & {$[65]$} \\
\hline BM-MSCs & $\begin{array}{l}\text { cAMP, bFGF, PDGF, } \\
\text { Heregulin } \beta 1\end{array}$ & $\mathrm{CM}$ & GDNF, BDNF & $\begin{array}{c}\text { Induction of striatal } \\
\text { dopaminergic nerve terminals } \\
\text { regeneration }\end{array}$ & {$[67]$} \\
\hline BM-MSCs & $\begin{array}{l}\text { cAMP, bFGF, PDGF, } \\
\text { Heregulin } \beta 1\end{array}$ & $\mathrm{CM}$ & GDNF, BDNF & $\begin{array}{l}\text { Reduction of striatal volume } \\
\text { changes associated with } \\
\text { quinolinic acid lesions }\end{array}$ & [68] \\
\hline BM-MSCs & Lithium, VPA & $\mathrm{CM}$ & - & $\begin{array}{l}\text { Improvement of motor and } \\
\text { behavior performance, and } \\
\text { reduction of neuronal death and } \\
\text { huntingtin aggregates in the } \\
\text { striatum }\end{array}$ & {$[70]$} \\
\hline DP-MSCs & bFGF; Hypoxia & $\mathrm{CM}$ & VEGF & Improvement of vascularization & [97] \\
\hline DP-MSCs & Hypoxia & $\mathrm{CM}$ & VEGF & Improvement of vascularization & [98] \\
\hline AdMSCs & Hypoxia & EXOs & - & $\begin{array}{l}\text { Increase of migration and tube } \\
\text { formation by HUVEC }\end{array}$ & [99] \\
\hline AdMSCs & Hypoxia & $\mathrm{CM}$ & VEGF, HGF, bFGF & $\begin{array}{c}\text { Increase of MSC angiogenic } \\
\text { potential }\end{array}$ & [101] \\
\hline WJ-MSCs & Hypoxia & $\mathrm{CM}$ & Angiogenin and VEGF & $\begin{array}{l}\text { Increase of migration and tube } \\
\text { formation angiogenesis }\end{array}$ & [102] \\
\hline AdMSCs & Hypoxia & $\mathrm{CM}$ & EGF, VEGF, FGF, HGF & $\begin{array}{l}\text { Improvement of functional } \\
\text { recovery and } \\
\text { neovascularization of the } \\
\text { ischemic tissue }\end{array}$ & [103] \\
\hline MSCs & Hypoxia & $\mathrm{CM}$ & VEGF & - & [108] \\
\hline BM-MSCs & Hypoxia & EXOs & miR-125 & $\begin{array}{l}\text { Improvement of cardiac } \\
\text { function }\end{array}$ & [110] \\
\hline BM-MSCs & IL-17 & $\mathrm{CM}$ & IL-6 & $\begin{array}{c}\text { Suppression of T cell } \\
\text { proliferation; inhibition of both } \\
\text { T cell activation and Th1 } \\
\text { cytokines }\end{array}$ & [119] \\
\hline $\begin{array}{l}\text { AdMSCs } \\
\text { BM-MSCs } \\
\text { CB-MSCs }\end{array}$ & IFN- $\gamma$ & $\mathrm{CM}$ & IDO & $\begin{array}{l}\text { Suppression of human } \\
\text { lymphocyte proliferation }\end{array}$ & [120] \\
\hline BM-MSCs & IL-17 & $\mathrm{CM}$ & IL-6 & $\mathrm{T}$ cell immunosuppression & [122] \\
\hline BM-MSCs & IFN- $\gamma ;$ TNF- $\alpha$ & $\mathrm{CM}$ & PGE2, IDO & Inhibition of allogeneic MLR & [123] \\
\hline
\end{tabular}


Table 1. Cont.

\begin{tabular}{|c|c|c|c|c|c|}
\hline MSCs & Priming Treatments & $\begin{array}{c}\text { MSC } \\
\text { Product }\end{array}$ & $\begin{array}{l}\text { Functional Factors } \\
\text { Detected }\end{array}$ & Biological Effects & Reference \\
\hline BM-MSCs & IFN- $\gamma ;$ LPS; TNF- $\alpha$ & $\mathrm{CM}$ & PGE2 & $\begin{array}{c}\text { Induction of monocytes } \\
\text { polarization toward an } \\
\text { anti-inflammatory M2 } \\
\text { phenotype }\end{array}$ & [124] \\
\hline BM-MSCs & IL- $1 \beta ;$ IFN- $\gamma$ & $\mathrm{CM}$ & IL-6 & $\begin{array}{c}\text { Induction of monocytes } \\
\text { polarization toward an } \\
\text { anti-inflammatory M2 } \\
\text { phenotype }\end{array}$ & [125] \\
\hline MSCs & IL- $1 \beta$ & EXOs & miR-21 & $\begin{array}{c}\text { Induced macrophage M2 } \\
\text { polarization and ameliorates } \\
\text { sepsis }\end{array}$ & [126] \\
\hline UC-MSCs & IL-1 $\beta$ & EXOs & miR-146a & $\begin{array}{c}\text { Amelioration of murine sepsis } \\
\text { and induction of monocytes } \\
\text { polarization toward an } \\
\text { anti-inflammatory M2 } \\
\text { phenotype }\end{array}$ & [127] \\
\hline BM-MSCs & IFN- $\gamma$; Spheroids & $\mathrm{CM}$ & IDO & $\begin{array}{l}\text { Suppression of T-cell activation } \\
\text { and proliferation in vitro }\end{array}$ & [128] \\
\hline BM-MSCs & Hypoxia & $\mathrm{CM}$ & PGE2, miR-210 & $\begin{array}{c}\text { Induced macrophage M2 } \\
\text { polarization and ameliorates } \\
\text { fibrosis }\end{array}$ & [137] \\
\hline
\end{tabular}

MSCs: mesenchymal stem cells; BM-MSCs: bone marrow-derived MSCs; AMSCs: amnion-derived MSCs; UC-MSCs: umbilical cordderived MSCs; AdMSCs: adipose-derived MSCs; CB-MSCs: cord blood-derived MSCs; GMSCs: gingival-derived MSCs; WJ-MSCs: Wharton's Jelly-derived MSCs; DP-MSCs: dental pulp-derived MSCs.

\section{Conclusions and Future Perspective}

In the last decade, the growing scientific interest in MSCs has clearly shown that these cells may have a significant therapeutic potential that can be applied in the field of regenerative medicine. Their action appears to be mediated by the release of paracrine modulators that orchestrate tissue repair/regeneration in a wide variety of diseases and disorders. Indeed, the emerging idea is that the CM derived from MSCs or its components (for example EXOs) may itself be sufficient for therapeutic activity.

There are currently a valuable number of clinical trials studying the effects of MSCs in many disorders (1213 studies at the time of writing, clinicaltrials.gov) and this number is increasing. However, clinical results suggest that MSCs have moderate or poor efficacy, thus being not very convincing in their applicability. MSC cultures might differ in their therapeutic capacity, and their heterogeneity also affects the MSC-derived secretomes that cause diverse effects on target cells. Therefore, it is essential that critical steps taken during the MSC production process should be more reproducible. Specific methods used to condition MSCs in stimulating their therapeutic functional properties could appropriately modify the therapeutic effects of the MSC secretome (Figure 2). For this reason, the strategy of strengthening the therapeutic potential of MSCs to direct their phenotype in therapeutically desirable ways is very appealing. Furthermore, the production of MSCderived products provides a useful technology to enhance MSCs' therapeutic potential and standardize the production of products intended for clinical use.

There is potential for improvement in MSC treatment and pretreating cells prior to use as therapeutic tool appear to be a promising strategy. A wide range of factors has been implicated in the paracrine therapeutic action of MSCs and further studies in this field must identify the best treatments and techniques that hold promise within specific disease models. Therefore, future experimental studies should define protocols for generation 
of MSC-derived products for each type of MSC population and for specific pathological conditions before MSC products can be applied in the field of regenerative medicine.

\section{PRIMING STIMULUS}

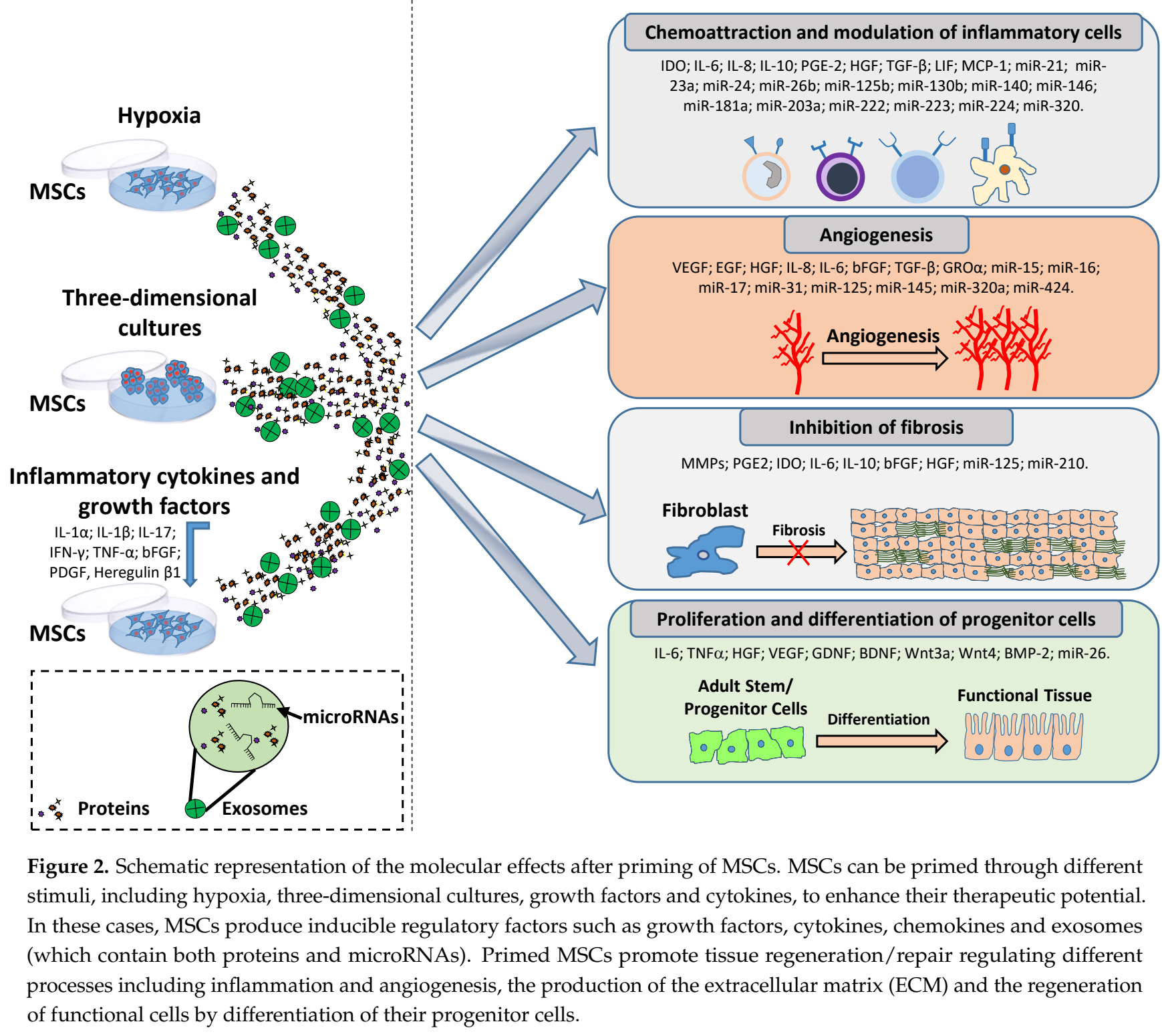

\section{BIOLOGICAL FUNCTION}




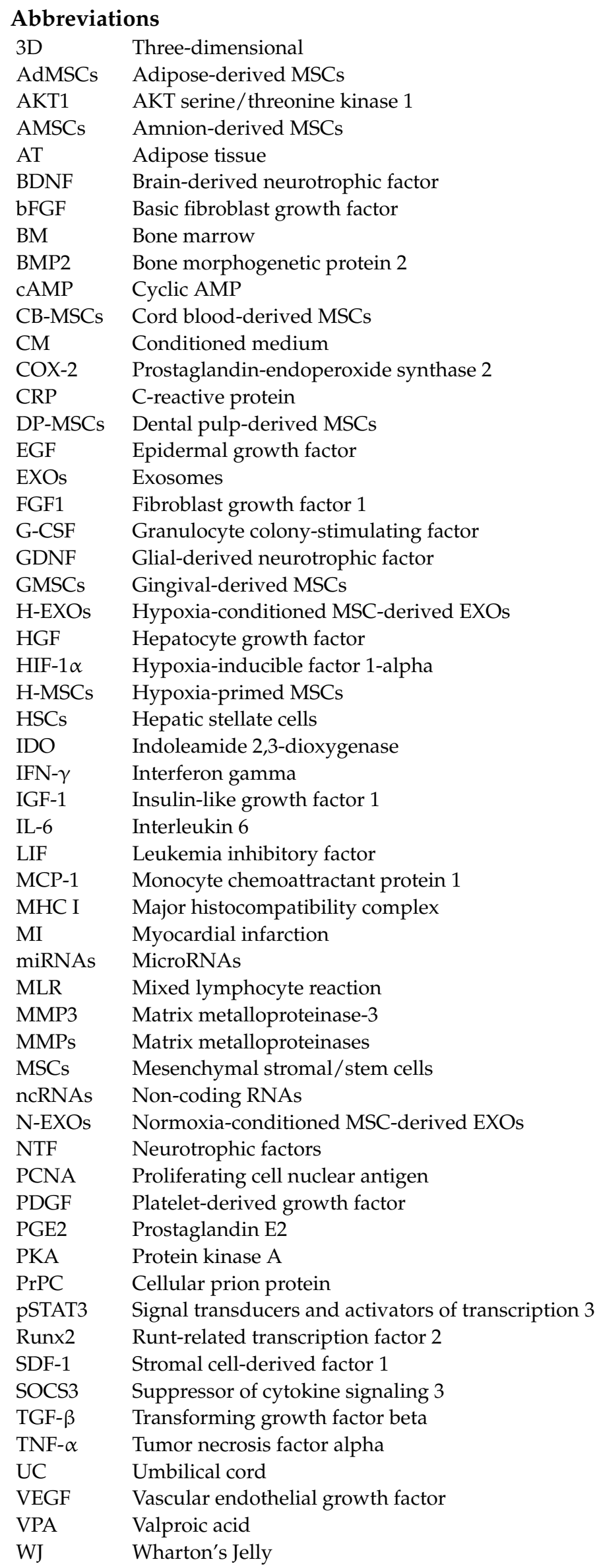




\section{References}

1. Degirmenci, B.; Valenta, T.; Dimitrieva, S.; Hausmann, G.; Basler, K. GLI1-expressing mesenchymal cells form the essential Wnt-secreting niche for colon stem cells. Nature 2018, 558, 449-453. [CrossRef] [PubMed]

2. Morrison, S.J.; Scadden, D.T. The bone marrow niche for haematopoietic stem cells. Nature 2014, 505, 327-334. [CrossRef] [PubMed]

3. Wosczyna, M.N.; Konishi, C.T.; Perez Carbajal, E.E.; Wang, T.T.; Walsh, R.A.; Gan, Q.; Wagner, M.W.; Rando, T.A. Mesenchymal Stromal Cells Are Required for Regeneration and Homeostatic Maintenance of Skeletal Muscle. Cell Rep. 2019, 27, 2029-2035.e5. [CrossRef] [PubMed]

4. Itkin, T.; Ludin, A.; Gradus, B.; Gur-Cohen, S.; Kalinkovich, A.; Schajnovitz, A.; Ovadya, Y.; Kollet, O.; Canaani, J.; Shezen, E.; et al. FGF-2 expands murine hematopoietic stem and progenitor cells via proliferation of stromal cells, c-Kit activation, and CXCL12 down-regulation. Blood 2012, 120, 1843-1855. [CrossRef] [PubMed]

5. Barker, N. Adult intestinal stem cells: Critical drivers of epithelial homeostasis and regeneration. Nat. Rev. Mol. Cell Biol. 2014, 15, 19-33. [CrossRef]

6. Hsu, Y.C.; Li, L.; Fuchs, E. Emerging interactions between skin stem cells and their niches. Nat. Med. 2014, 20, 847-856. [CrossRef]

7. Brack, A.S.; Rando, T.A. Tissue-specific stem cells: Lessons from the skeletal muscle satellite cell. Cell Stem Cell 2012, 10, 504-514. [CrossRef]

8. Joe, A.W.; Yi, L.; Natarajan, A.; Le Grand, F.; So, L.; Wang, J.; Rudnicki, M.A.; Rossi, F.M. Muscle injury activates resident fibro/adipogenic progenitors that facilitate myogenesis. Nat. Cell Biol. 2010, 12, 153-163. [CrossRef]

9. Festa, E.; Fretz, J.; Berry, R.; Schmidt, B.; Rodeheffer, M.; Horowitz, M.; Horsley, V. Adipocyte lineage cells contribute to the skin stem cell niche to drive hair cycling. Cell 2011, 146, 761-771. [CrossRef]

10. Zhao, Q.; Gregory, C.A.; Lee, R.H.; Reger, R.L.; Qin, L.; Hai, B.; Park, M.S.; Yoon, N.; Clough, B.; McNeill, E.; et al. MSCs derived from iPSCs with a modified protocol are tumor-tropic but have much less potential to promote tumors than bone marrow MSCs. Proc. Natl. Acad. Sci. USA 2015, 112, 530-535. [CrossRef]

11. Jacobs, S.A.; Roobrouck, V.D.; Verfaillie, C.M.; Van Gool, S.W. Immunological characteristics of human mesenchymal stem cells and multipotent adult progenitor cells. Immunol. Cell Biol. 2013, 91, 32-39. [CrossRef] [PubMed]

12. Le Blanc, K.; Tammik, C.; Rosendahl, K.; Zetterberg, E.; Ringden, O. HLA expression and immunologic properties of differentiated and undifferentiated mesenchymal stem cells. Exp. Hematol. 2003, 31, 890-896. [CrossRef]

13. Stagg, J.; Pommey, S.; Eliopoulos, N.; Galipeau, J. Interferon-gamma-stimulated marrow stromal cells: A new type of nonhematopoietic antigen-presenting cell. Blood 2006, 107, 2570-2577. [CrossRef] [PubMed]

14. Ullah, I.; Subbarao, R.B.; Rho, G.J. Human mesenchymal stem cells-current trends and future prospective. Biosci. Rep. 2015, 35, e00191. [CrossRef]

15. Walter, S.G.; Randau, T.M.; Hilgers, C.; Haddouti, E.M.; Masson, W.; Gravius, S.; Burger, C.; Wirtz, D.C.; Schildberg, F.A. Molecular and Functional Phenotypes of Human Bone Marrow-Derived Mesenchymal Stromal Cells Depend on Harvesting Techniques. Int. J. Mol. Sci. 2020, 21, 4382. [CrossRef]

16. Burja, B.; Barlic, A.; Erman, A.; Mrak-Poljsak, K.; Tomsic, M.; Sodin-Semrl, S.; Lakota, K. Human mesenchymal stromal cells from different tissues exhibit unique responses to different inflammatory stimuli. Curr. Res. Transl. Med. 2020, 68, 217-224. [CrossRef]

17. Tesarova, L.; Jaresova, K.; Simara, P.; Koutna, I. Umbilical Cord-Derived Mesenchymal Stem Cells Are Able to Use bFGF Treatment and Represent a Superb Tool for Immunosuppressive Clinical Applications. Int. J. Mol. Sci. 2020, 21, 5336. [CrossRef]

18. Gronthos, S.; Mankani, M.; Brahim, J.; Robey, P.G.; Shi, S. Postnatal human dental pulp stem cells (DPSCs) in vitro and in vivo. Proc. Natl. Acad. Sci. USA 2000, 97, 13625-13630. [CrossRef]

19. Parolini, O.; Alviano, F.; Bagnara, G.P.; Bilic, G.; Buhring, H.J.; Evangelista, M.; Hennerbichler, S.; Liu, B.; Magatti, M.; Mao, N.; et al. Concise review: Isolation and characterization of cells from human term placenta: Outcome of the first international Workshop on Placenta Derived Stem Cells. Stem Cells 2008, 26, 300-311. [CrossRef]

20. Bulati, M.; Miceli, V.; Gallo, A.; Amico, G.; Carcione, C.; Pampalone, M.; Conaldi, P.G. The Immunomodulatory Properties of the Human Amnion-Derived Mesenchymal Stromal/Stem Cells Are Induced by INF-gamma Produced by Activated Lymphomonocytes and Are Mediated by Cell-To-Cell Contact and Soluble Factors. Front. Immunol. 2020, 11, 54. [CrossRef]

21. Poggi, A.; Zocchi, M.R. Immunomodulatory Properties of Mesenchymal Stromal Cells: Still Unresolved "Yin and Yang". Curr. Stem Cell Res. Ther. 2019, 14, 344-350. [CrossRef] [PubMed]

22. Fan, X.L.; Zhang, Y.; Li, X.; Fu, Q.L. Mechanisms underlying the protective effects of mesenchymal stem cell-based therapy. Cell. Mol. Life Sci. CMLS 2020, 77, 2771-2794. [CrossRef] [PubMed]

23. Tao, H.; Han, Z.; Han, Z.C.; Li, Z. Proangiogenic Features of Mesenchymal Stem Cells and Their Therapeutic Applications. Stem Cells Int. 2016, 2016, 1314709. [CrossRef] [PubMed]

24. Stavely, R.; Nurgali, K. The emerging antioxidant paradigm of mesenchymal stem cell therapy. Stem Cells Transl. Med. 2020, 9 , 985-1006. [CrossRef]

25. Fricova, D.; Korchak, J.A.; Zubair, A.C. Challenges and translational considerations of mesenchymal stem/stromal cell therapy for Parkinson's disease. NPJ Regen. Med. 2020, 5, 20. [CrossRef]

26. Lukomska, B.; Stanaszek, L.; Zuba-Surma, E.; Legosz, P.; Sarzynska, S.; Drela, K. Challenges and Controversies in Human Mesenchymal Stem Cell Therapy. Stem Cells Int. 2019, 2019, 9628536. [CrossRef] 
27. Malliaras, K.; Kreke, M.; Marban, E. The stuttering progress of cell therapy for heart disease. Clin. Pharmacol. Ther. 2011, 90, 532-541. [CrossRef]

28. Squillaro, T.; Peluso, G.; Galderisi, U. Clinical Trials with Mesenchymal Stem Cells: An Update. Cell Transplant. 2016, 25, 829-848. [CrossRef]

29. Tyndall, A. Successes and failures of stem cell transplantation in autoimmune diseases. Hematol. Am. Soc. Hematol. Educ. Program 2011, 2011, 280-284. [CrossRef]

30. Maacha, S.; Sidahmed, H.; Jacob, S.; Gentilcore, G.; Calzone, R.; Grivel, J.C.; Cugno, C. Paracrine Mechanisms of Mesenchymal Stromal Cells in Angiogenesis. Stem Cells Int. 2020, 2020, 4356359. [CrossRef]

31. Schmelzer, E.; Miceli, V.; Chinnici, C.M.; Bertani, A.; Gerlach, J.C. Effects of Mesenchymal Stem Cell Coculture on Human Lung Small Airway Epithelial Cells. BioMed Res. Int. 2020, 2020, 9847579. [CrossRef] [PubMed]

32. Cunningham, C.J.; Redondo-Castro, E.; Allan, S.M. The therapeutic potential of the mesenchymal stem cell secretome in ischaemic stroke. J. Cereb. Blood Flow Metab. Off. J. Int. Soc. Cereb. Blood Flow Metab. 2018, 38, 1276-1292. [CrossRef] [PubMed]

33. Ferreira, J.R.; Teixeira, G.Q.; Santos, S.G.; Barbosa, M.A.; Almeida-Porada, G.; Goncalves, R.M. Mesenchymal Stromal Cell Secretome: Influencing Therapeutic Potential by Cellular Pre-conditioning. Front. Immunol. 2018, 9, 2837. [CrossRef] [PubMed]

34. Miceli, V.; Chinnici, C.M.; Bulati, M.; Pampalone, M.; Amico, G.; Schmelzer, E.; Gerlach, J.C.; Conaldi, P.G. Comparative study of the production of soluble factors in human placenta-derived mesenchymal stromal/stem cells grown in adherent conditions or as aggregates in a catheter-like device. Biochem. Biophys. Res. Commun. 2020, 522, 171-176. [CrossRef] [PubMed]

35. Miceli, V.; Pampalone, M.; Vella, S.; Carreca, A.P.; Amico, G.; Conaldi, P.G. Comparison of Immunosuppressive and Angiogenic Properties of Human Amnion-Derived Mesenchymal Stem Cells between 2D and 3D Culture Systems. Stem Cells Int. 2019, 2019, 7486279. [CrossRef] [PubMed]

36. Redondo-Castro, E.; Cunningham, C.; Miller, J.; Martuscelli, L.; Aoulad-Ali, S.; Rothwell, N.J.; Kielty, C.M.; Allan, S.M.; Pinteaux, E. Interleukin-1 primes human mesenchymal stem cells towards an anti-inflammatory and pro-trophic phenotype in vitro. Stem Cell Res. Ther. 2017, 8, 79. [CrossRef]

37. Wang, Y.; Chen, X.; Cao, W.; Shi, Y. Plasticity of mesenchymal stem cells in immunomodulation: Pathological and therapeutic implications. Nat. Immunol. 2014, 15, 1009-1016. [CrossRef]

38. Neirinckx, V.; Coste, C.; Rogister, B.; Wislet-Gendebien, S. Concise review: Adult mesenchymal stem cells, adult neural crest stem cells, and therapy of neurological pathologies: A state of play. Stem Cells Transl. Med. 2013, 2, 284-296. [CrossRef]

39. Nuzzi, R.; Caselgrandi, P.; Vercelli, A. Effect of Mesenchymal Stem Cell-Derived Exosomes on Retinal Injury: A Review of Current Findings. Stem Cells Int. 2020, 2020, 8883616. [CrossRef]

40. Qian, X.; An, N.; Ren, Y.; Yang, C.; Zhang, X.; Li, L. Immunosuppressive Effects of Mesenchymal Stem Cells-derived Exosomes. Stem Cell Rev. Rep. 2020. [CrossRef]

41. Sinclair, K.; Yerkovich, S.T.; Chambers, D.C. Mesenchymal stem cells and the lung. Respirology 2013, 18, 397-411. [CrossRef] [PubMed]

42. Sun, H.; Pratt, R.E.; Hodgkinson, C.P.; Dzau, V.J. Sequential paracrine mechanisms are necessary for the therapeutic benefits of stem cell therapy. Am. J. Physiol. Cell Physiol. 2020, 319, C1141-C1150. [CrossRef] [PubMed]

43. Wang, M.; Yan, L.; Li, Q.; Yang, Y.; Turrentine, M.; March, K.; Wang, I.W. Mesenchymal stem cell secretions improve donor heart function following ex vivo cold storage. J. Thorac. Cardiovasc. Surg. 2020. [CrossRef] [PubMed]

44. Zhu, X.Y.; Lerman, A.; Lerman, L.O. Concise review: Mesenchymal stem cell treatment for ischemic kidney disease. Stem Cells 2013, 31, 1731-1736. [CrossRef] [PubMed]

45. Fayyad-Kazan, M.; Fayyad-Kazan, H.; Lagneaux, L.; Najar, M. The potential of mesenchymal stromal cells in immunotherapy. Immunotherapy 2016, 8, 839-842. [CrossRef]

46. Fu, X.; Liu, G.; Halim, A.; Ju, Y.; Luo, Q.; Song, A.G. Mesenchymal Stem Cell Migration and Tissue Repair. Cells 2019, 8, 784. [CrossRef]

47. Xi, J.; Yan, X.; Zhou, J.; Yue, W.; Pei, X. Mesenchymal stem cells in tissue repairing and regeneration: Progress and future. Burn. Trauma 2013, 1, 13-20.

48. Butler, J.; Epstein, S.E.; Greene, S.J.; Quyyumi, A.A.; Sikora, S.; Kim, R.J.; Anderson, A.S.; Wilcox, J.E.; Tankovich, N.I.; Lipinski, M.J.; et al. Intravenous Allogeneic Mesenchymal Stem Cells for Nonischemic Cardiomyopathy: Safety and Efficacy Results of a Phase II-A Randomized Trial. Circ. Res. 2017, 120, 332-340. [CrossRef]

49. Costa-Almeida, R.; Calejo, I.; Gomes, M.E. Mesenchymal Stem Cells Empowering Tendon Regenerative Therapies. Int. J. Mol. Sci. 2019, 20, 3002. [CrossRef]

50. Hare, J.M.; DiFede, D.L.; Rieger, A.C.; Florea, V.; Landin, A.M.; El-Khorazaty, J.; Khan, A.; Mushtaq, M.; Lowery, M.H.; Byrnes, J.J.; et al. Randomized Comparison of Allogeneic Versus Autologous Mesenchymal Stem Cells for Nonischemic Dilated Cardiomyopathy: POSEIDON-DCM Trial. J. Am. Coll. Cardiol. 2017, 69, 526-537. [CrossRef]

51. Sagaradze, G.; Basalova, N.; Kirpatovsky, V.; Ohobotov, D.; Nimiritsky, P.; Grigorieva, O.; Popov, V.; Kamalov, A.; Tkachuk, V.; Efimenko, A. A magic kick for regeneration: Role of mesenchymal stromal cell secretome in spermatogonial stem cell niche recovery. Stem Cell Res. Ther. 2019, 10, 342. [CrossRef]

52. Vizoso, F.J.; Eiro, N.; Cid, S.; Schneider, J.; Perez-Fernandez, R. Mesenchymal Stem Cell Secretome: Toward Cell-Free Therapeutic Strategies in Regenerative Medicine. Int. J. Mol. Sci. 2017, 18, 1852. [CrossRef] [PubMed] 
53. Ankrum, J.; Karp, J.M. Mesenchymal stem cell therapy: Two steps forward, one step back. Trends Mol. Med. 2010, 16, 203-209. [CrossRef]

54. Crisan, M.; Yap, S.; Casteilla, L.; Chen, C.W.; Corselli, M.; Park, T.S.; Andriolo, G.; Sun, B.; Zheng, B.; Zhang, L.; et al. A perivascular origin for mesenchymal stem cells in multiple human organs. Cell Stem Cell 2008, 3, 301-313. [CrossRef] [PubMed]

55. Davies, J.E.; Walker, J.T.; Keating, A. Concise Review: Wharton's Jelly: The Rich, but Enigmatic, Source of Mesenchymal Stromal Cells. Stem Cells Transl. Med. 2017, 6, 1620-1630. [CrossRef] [PubMed]

56. Lee, S.C.; Jeong, H.J.; Lee, S.K.; Kim, S.J. Hypoxic Conditioned Medium from Human Adipose-Derived Stem Cells Promotes Mouse Liver Regeneration Through JAK/STAT3 Signaling. Stem Cells Transl. Med. 2016, 5, 816-825. [CrossRef] [PubMed]

57. Yu, J.; Yin, S.; Zhang, W.; Gao, F.; Liu, Y.; Chen, Z.; Zhang, M.; He, J.; Zheng, S. Hypoxia preconditioned bone marrow mesenchymal stem cells promote liver regeneration in a rat massive hepatectomy model. Stem Cell Res. Ther. 2013, 4, 83. [CrossRef] [PubMed]

58. Leroux, L.; Descamps, B.; Tojais, N.F.; Seguy, B.; Oses, P.; Moreau, C.; Daret, D.; Ivanovic, Z.; Boiron, J.M.; Lamaziere, J.M.; et al. Hypoxia preconditioned mesenchymal stem cells improve vascular and skeletal muscle fiber regeneration after ischemia through a Wnt4-dependent pathway. Mol. Ther. J. Am. Soc. Gene Ther. 2010, 18, 1545-1552. [CrossRef] [PubMed]

59. Hu, X.; Xu, Y.; Zhong, Z.; Wu, Y.; Zhao, J.; Wang, Y.; Cheng, H.; Kong, M.; Zhang, F.; Chen, Q.; et al. A Large-Scale Investigation of Hypoxia-Preconditioned Allogeneic Mesenchymal Stem Cells for Myocardial Repair in Nonhuman Primates: Paracrine Activity Without Remuscularization. Circ. Res. 2016, 118, 970-983. [CrossRef]

60. Park, H.; Park, H.; Mun, D.; Kang, J.; Kim, H.; Kim, M.; Cui, S.; Lee, S.H.; Joung, B. Extracellular Vesicles Derived from Hypoxic Human Mesenchymal Stem Cells Attenuate GSK3beta Expression via miRNA-26a in an Ischemia-Reperfusion Injury Model. Yonsei Med. J. 2018, 59, 736-745. [CrossRef]

61. Chang, C.P.; Chio, C.C.; Cheong, C.U.; Chao, C.M.; Cheng, B.C.; Lin, M.T. Hypoxic preconditioning enhances the therapeutic potential of the secretome from cultured human mesenchymal stem cells in experimental traumatic brain injury. Clin. Sci. 2013, 124, 165-176. [CrossRef] [PubMed]

62. Zhilai, Z.; Biling, M.; Sujun, Q.; Chao, D.; Benchao, S.; Shuai, H.; Shun, Y.; Hui, Z. Preconditioning in lowered oxygen enhances the therapeutic potential of human umbilical mesenchymal stem cells in a rat model of spinal cord injury. Brain Res. 2016, 1642, 426-435. [CrossRef] [PubMed]

63. Lu, Z.; Wang, G.; Dunstan, C.R.; Chen, Y.; Lu, W.Y.; Davies, B.; Zreiqat, H. Activation and promotion of adipose stem cells by tumour necrosis factor-alpha preconditioning for bone regeneration. J. Cell. Physiol. 2013, 228, 1737-1744. [CrossRef] [PubMed]

64. Lu, Z.; Chen, Y.; Dunstan, C.; Roohani-Esfahani, S.; Zreiqat, H. Priming Adipose Stem Cells with Tumor Necrosis Factor-Alpha Preconditioning Potentiates Their Exosome Efficacy for Bone Regeneration. Tissue Eng. Part A 2017, 23, 1212-1220. [CrossRef] [PubMed]

65. Novais, A.; Lesieur, J.; Sadoine, J.; Slimani, L.; Baroukh, B.; Saubamea, B.; Schmitt, A.; Vital, S.; Poliard, A.; Helary, C.; et al. Priming Dental Pulp Stem Cells from Human Exfoliated Deciduous Teeth with Fibroblast Growth Factor-2 Enhances Mineralization Within Tissue-Engineered Constructs Implanted in Craniofacial Bone Defects. Stem Cells Transl. Med. 2019, 8, 844-857. [CrossRef] [PubMed]

66. Gothelf, Y.; Abramov, N.; Harel, A.; Offen, D. Safety of repeated transplantations of neurotrophic factors-secreting human mesenchymal stromal stem cells. Clin. Transl. Med. 2014, 3, 21. [CrossRef]

67. Sadan, O.; Bahat-Stromza, M.; Barhum, Y.; Levy, Y.S.; Pisnevsky, A.; Peretz, H.; Ilan, A.B.; Bulvik, S.; Shemesh, N.; Krepel, D.; et al. Protective effects of neurotrophic factor-secreting cells in a 6-OHDA rat model of Parkinson disease. Stem Cells Dev. 2009, 18, 1179-1190. [CrossRef]

68. Sadan, O.; Melamed, E.; Offen, D. Bone-marrow-derived mesenchymal stem cell therapy for neurodegenerative diseases. Expert Opin. Biol. Ther. 2009, 9, 1487-1497. [CrossRef]

69. Sadan, O.; Shemesh, N.; Barzilay, R.; Dadon-Nahum, M.; Blumenfeld-Katzir, T.; Assaf, Y.; Yeshurun, M.; Djaldetti, R.; Cohen, Y.; Melamed, E.; et al. Mesenchymal stem cells induced to secrete neurotrophic factors attenuate quinolinic acid toxicity: A potential therapy for Huntington's disease. Exp. Neurol. 2012, 234, 417-427. [CrossRef]

70. Linares, G.R.; Chiu, C.T.; Scheuing, L.; Leng, Y.; Liao, H.M.; Maric, D.; Chuang, D.M. Preconditioning mesenchymal stem cells with the mood stabilizers lithium and valproic acid enhances therapeutic efficacy in a mouse model of Huntington's disease. Exp. Neurol. 2016, 281, 81-92. [CrossRef]

71. Raggi, C.; Berardi, A.C. Mesenchymal stem cells, aging and regenerative medicine. Muscles Ligaments Tendons J. $2012,2,239-242$. [PubMed]

72. Yu, K.R.; Kang, K.S. Aging-related genes in mesenchymal stem cells: A mini-review. Gerontology 2013, 59, 557-563. [CrossRef] [PubMed]

73. Sousa-Victor, P.; Gutarra, S.; Garcia-Prat, L.; Rodriguez-Ubreva, J.; Ortet, L.; Ruiz-Bonilla, V.; Jardi, M.; Ballestar, E.; Gonzalez, S.; Serrano, A.L.; et al. Geriatric muscle stem cells switch reversible quiescence into senescence. Nature 2014, 506, 316-321. [CrossRef] [PubMed]

74. Geissler, S.; Textor, M.; Schmidt-Bleek, K.; Klein, O.; Thiele, M.; Ellinghaus, A.; Jacobi, D.; Ode, A.; Perka, C.; Dienelt, A.; et al. In serum veritas-in serum sanitas? Cell non-autonomous aging compromises differentiation and survival of mesenchymal stromal cells via the oxidative stress pathway. Cell Death Dis. 2013, 4, e970. [CrossRef]

75. Jones, D.L.; Rando, T.A. Emerging models and paradigms for stem cell ageing. Nat. Cell Biol. 2011, 13, 506-512. [CrossRef] [PubMed] 
76. Schulman, I.H.; Balkan, W.; Hare, J.M. Mesenchymal Stem Cell Therapy for Aging Frailty. Front. Nutr. 2018, 5, 108. [CrossRef]

77. Bagno, L.; Hatzistergos, K.E.; Balkan, W.; Hare, J.M. Mesenchymal Stem Cell-Based Therapy for Cardiovascular Disease: Progress and Challenges. Mol. Ther. J. Am. Soc. Gene Ther. 2018, 26, 1610-1623. [CrossRef]

78. Golpanian, S.; El-Khorazaty, J.; Mendizabal, A.; DiFede, D.L.; Suncion, V.Y.; Karantalis, V.; Fishman, J.E.; Ghersin, E.; Balkan, W.; Hare, J.M. Effect of aging on human mesenchymal stem cell therapy in ischemic cardiomyopathy patients. J. Am. Coll. Cardiol. 2015, 65, 125-132. [CrossRef]

79. Fontaine, M.J.; Shih, H.; Schafer, R.; Pittenger, M.F. Unraveling the Mesenchymal Stromal Cells' Paracrine Immunomodulatory Effects. Transfus. Med. Rev. 2016, 30, 37-43. [CrossRef]

80. Najar, M.; Krayem, M.; Merimi, M.; Burny, A.; Meuleman, N.; Bron, D.; Raicevic, G.; Lagneaux, L. Insights into inflammatory priming of mesenchymal stromal cells: Functional biological impacts. Inflamm. Res. Off. J. Eur. Histamine Res. Soc. 2018, 67, 467-477. [CrossRef]

81. Caplan, A.I.; Dennis, J.E. Mesenchymal stem cells as trophic mediators. J. Cell. Biochem. 2006, 98, 1076-1084. [CrossRef] [PubMed]

82. Valadi, H.; Ekstrom, K.; Bossios, A.; Sjostrand, M.; Lee, J.J.; Lotvall, J.O. Exosome-mediated transfer of mRNAs and microRNAs is a novel mechanism of genetic exchange between cells. Nat. Cell Biol. 2007, 9, 654-659. [CrossRef] [PubMed]

83. Beer, L.; Mildner, M.; Ankersmit, H.J. Cell secretome based drug substances in regenerative medicine: When regulatory affairs meet basic science. Ann. Transl. Med. 2017, 5, 170. [CrossRef] [PubMed]

84. Hsiao, S.T.; Asgari, A.; Lokmic, Z.; Sinclair, R.; Dusting, G.J.; Lim, S.Y.; Dilley, R.J. Comparative analysis of paracrine factor expression in human adult mesenchymal stem cells derived from bone marrow, adipose, and dermal tissue. Stem Cells Dev. 2012, 21, 2189-2203. [CrossRef] [PubMed]

85. Kehl, D.; Generali, M.; Mallone, A.; Heller, M.; Uldry, A.C.; Cheng, P.; Gantenbein, B.; Hoerstrup, S.P.; Weber, B. Proteomic analysis of human mesenchymal stromal cell secretomes: A systematic comparison of the angiogenic potential. NPJ Regen. Med. 2019, 4, 8. [CrossRef]

86. Krawczenko, A.; Bielawska-Pohl, A.; Paprocka, M.; Kraskiewicz, H.; Szyposzynska, A.; Wojdat, E.; Klimczak, A. Microvesicles from Human Immortalized Cell Lines of Endothelial Progenitor Cells and Mesenchymal Stem/Stromal Cells of Adipose Tissue Origin as Carriers of Bioactive Factors Facilitating Angiogenesis. Stem Cells Int. 2020, 2020, 1289380. [CrossRef]

87. Kwon, H.M.; Hur, S.M.; Park, K.Y.; Kim, C.K.; Kim, Y.M.; Kim, H.S.; Shin, H.C.; Won, M.H.; Ha, K.S.; Kwon, Y.G.; et al. Multiple paracrine factors secreted by mesenchymal stem cells contribute to angiogenesis. Vasc. Pharmacol. 2014, 63, 19-28. [CrossRef]

88. Almeria, C.; Weiss, R.; Roy, M.; Tripisciano, C.; Kasper, C.; Weber, V.; Egger, D. Hypoxia Conditioned Mesenchymal Stem Cell-Derived Extracellular Vesicles Induce Increased Vascular Tube Formation in vitro. Front. Bioeng. Biotechnol. $2019,7,292$. [CrossRef]

89. Bader, A.M.; Klose, K.; Bieback, K.; Korinth, D.; Schneider, M.; Seifert, M.; Choi, Y.H.; Kurtz, A.; Falk, V.; Stamm, C. Hypoxic Preconditioning Increases Survival and Pro-Angiogenic Capacity of Human Cord Blood Mesenchymal Stromal Cells In Vitro. PLoS ONE 2015, 10, e0138477. [CrossRef]

90. Fierro, F.A.; O'Neal, A.J.; Beegle, J.R.; Chavez, M.N.; Peavy, T.R.; Isseroff, R.R.; Egana, J.T. Hypoxic pre-conditioning increases the infiltration of endothelial cells into scaffolds for dermal regeneration pre-seeded with mesenchymal stem cells. Front. Cell Dev. Biol. 2015, 3, 68. [CrossRef]

91. Han, K.H.; Kim, A.K.; Kim, M.H.; Kim, D.H.; Go, H.N.; Kim, D.I. Enhancement of angiogenic effects by hypoxia-preconditioned human umbilical cord-derived mesenchymal stem cells in a mouse model of hindlimb ischemia. Cell Biol. Int. 2016, 40, 27-35. [CrossRef] [PubMed]

92. Kang, I.; Lee, B.C.; Choi, S.W.; Lee, J.Y.; Kim, J.J.; Kim, B.E.; Kim, D.H.; Lee, S.E.; Shin, N.; Seo, Y.; et al. Donor-dependent variation of human umbilical cord blood mesenchymal stem cells in response to hypoxic preconditioning and amelioration of limb ischemia. Exp. Mol. Med. 2018, 50, 35. [CrossRef] [PubMed]

93. Liu, W.; Li, L.; Rong, Y.; Qian, D.; Chen, J.; Zhou, Z.; Luo, Y.; Jiang, D.; Cheng, L.; Zhao, S.; et al. Hypoxic mesenchymal stem cell-derived exosomes promote bone fracture healing by the transfer of miR-126. Acta Biomater. 2020, 103, 196-212. [CrossRef]

94. Salomon, C.; Ryan, J.; Sobrevia, L.; Kobayashi, M.; Ashman, K.; Mitchell, M.; Rice, G.E. Exosomal signaling during hypoxia mediates microvascular endothelial cell migration and vasculogenesis. PLoS ONE 2013, 8, e68451. [CrossRef] [PubMed]

95. Yang, H.Y.; Fierro, F.; So, M.; Yoon, D.J.; Nguyen, A.V.; Gallegos, A.; Bagood, M.D.; Rojo-Castro, T.; Alex, A.; Stewart, H.; et al. Combination product of dermal matrix, human mesenchymal stem cells, and timolol promotes diabetic wound healing in mice. Stem Cells Transl. Med. 2020, 9, 1353-1364. [CrossRef]

96. Zhang, H.C.; Liu, X.B.; Huang, S.; Bi, X.Y.; Wang, H.X.; Xie, L.X.; Wang, Y.Q.; Cao, X.F.; Lv, J.; Xiao, F.J.; et al. Microvesicles derived from human umbilical cord mesenchymal stem cells stimulated by hypoxia promote angiogenesis both in vitro and in vivo. Stem Cells Dev. 2012, 21, 3289-3297. [CrossRef]

97. Gorin, C.; Rochefort, G.Y.; Bascetin, R.; Ying, H.; Lesieur, J.; Sadoine, J.; Beckouche, N.; Berndt, S.; Novais, A.; Lesage, M.; et al. Priming Dental Pulp Stem Cells with Fibroblast Growth Factor-2 Increases Angiogenesis of Implanted Tissue-Engineered Constructs Through Hepatocyte Growth Factor and Vascular Endothelial Growth Factor Secretion. Stem Cells Transl. Med. 2016, 5, 392-404. [CrossRef]

98. Kuang, R.; Zhang, Z.; Jin, X.; Hu, J.; Shi, S.; Ni, L.; Ma, P.X. Nanofibrous spongy microspheres for the delivery of hypoxia-primed human dental pulp stem cells to regenerate vascularized dental pulp. Acta Biomater. 2016, 33, 225-234. [CrossRef] 
99. Xue, C.; Shen, Y.; Li, X.; Li, B.; Zhao, S.; Gu, J.; Chen, Y.; Ma, B.; Wei, J.; Han, Q.; et al. Exosomes Derived from Hypoxia-Treated Human Adipose Mesenchymal Stem Cells Enhance Angiogenesis Through the PKA Signaling Pathway. Stem Cells Dev. 2018, 27, 456-465. [CrossRef]

100. Mathew, S.A.; Chandravanshi, B.; Bhonde, R. Hypoxia primed placental mesenchymal stem cells for wound healing. Life Sci. 2017, 182, 85-92. [CrossRef]

101. Lee, J.H.; Yoon, Y.M.; Lee, S.H. Hypoxic Preconditioning Promotes the Bioactivities of Mesenchymal Stem Cells via the HIF1alpha-GRP78-Akt Axis. Int. J. Mol. Sci. 2017, 18, 1320. [CrossRef] [PubMed]

102. Lee, S.G.; Joe, Y.A. Autophagy mediates enhancement of proangiogenic activity by hypoxia in mesenchymal stromal/stem cells. Biochem. Biophys. Res. Commun. 2018, 501, 941-947. [CrossRef] [PubMed]

103. Han, Y.S.; Lee, J.H.; Yoon, Y.M.; Yun, C.W.; Noh, H.; Lee, S.H. Hypoxia-induced expression of cellular prion protein improves the therapeutic potential of mesenchymal stem cells. Cell Death Dis. 2016, 7, e2395. [CrossRef] [PubMed]

104. Komaki, M.; Numata, Y.; Morioka, C.; Honda, I.; Tooi, M.; Yokoyama, N.; Ayame, H.; Iwasaki, K.; Taki, A.; Oshima, N.; et al. Exosomes of human placenta-derived mesenchymal stem cells stimulate angiogenesis. Stem Cell Res. Ther. 2017, 8, 219. [CrossRef]

105. Keerthikumar, S.; Chisanga, D.; Ariyaratne, D.; Al Saffar, H.; Anand, S.; Zhao, K.; Samuel, M.; Pathan, M.; Jois, M.; Chilamkurti, N.; et al. ExoCarta: A Web-Based Compendium of Exosomal Cargo. J. Mol. Biol. 2016, 428, 688-692. [CrossRef]

106. Gallo, A.; Bulati, M.; Miceli, V.; Amodio, N.; Conaldi, P.G. Non-Coding RNAs: Strategy for Viruses' Offensive. Non-Coding RNA 2020, 6, 38. [CrossRef]

107. Kane, N.M.; Thrasher, A.J.; Angelini, G.D.; Emanueli, C. Concise review: MicroRNAs as modulators of stem cells and angiogenesis. Stem Cells 2014, 32, 1059-1066. [CrossRef]

108. Costa, V.; Raimondi, L.; Conigliaro, A.; Salamanna, F.; Carina, V.; De Luca, A.; Bellavia, D.; Alessandro, R.; Fini, M.; Giavaresi, G. Hypoxia-inducible factor 1Alpha may regulate the commitment of mesenchymal stromal cells toward angio-osteogenesis by mirna-675-5P. Cytotherapy 2017, 19, 1412-1425. [CrossRef]

109. Gonzalez-King, H.; Garcia, N.A.; Ontoria-Oviedo, I.; Ciria, M.; Montero, J.A.; Sepulveda, P. Hypoxia Inducible Factor-1alpha Potentiates Jagged 1-Mediated Angiogenesis by Mesenchymal Stem Cell-Derived Exosomes. Stem Cells 2017, 35, 1747-1759. [CrossRef]

110. Zhu, L.P.; Tian, T.; Wang, J.Y.; He, J.N.; Chen, T.; Pan, M.; Xu, L.; Zhang, H.X.; Qiu, X.T.; Li, C.C.; et al. Hypoxia-elicited mesenchymal stem cell-derived exosomes facilitates cardiac repair through miR-125b-mediated prevention of cell death in myocardial infarction. Theranostics 2018, 8, 6163-6177. [CrossRef]

111. Zhou, Y.; Yamamoto, Y.; Xiao, Z.; Ochiya, T. The Immunomodulatory Functions of Mesenchymal Stromal/Stem Cells Mediated via Paracrine Activity. J. Clin. Med. 2019, 8, 1025. [CrossRef] [PubMed]

112. Zhao, L.; Hu, C.; Zhang, P.; Jiang, H.; Chen, J. Preconditioning strategies for improving the survival rate and paracrine ability of mesenchymal stem cells in acute kidney injury. J. Cell. Mol. Med. 2019, 23, 720-730. [CrossRef] [PubMed]

113. Hu, J.; Zhang, L.; Wang, N.; Ding, R.; Cui, S.; Zhu, F.; Xie, Y.; Sun, X.; Wu, D.; Hong, Q.; et al. Mesenchymal stem cells attenuate ischemic acute kidney injury by inducing regulatory T cells through splenocyte interactions. Kidney Int. 2013, 84, 521-531. [CrossRef] [PubMed]

114. Ma, X.; Che, N.; Gu, Z.; Huang, J.; Wang, D.; Liang, J.; Hou, Y.; Gilkeson, G.; Lu, L.; Sun, L. Allogenic mesenchymal stem cell transplantation ameliorates nephritis in lupus mice via inhibition of B-cell activation. Cell Transplant. 2013, 22, 2279-2290. [CrossRef] [PubMed]

115. Yagi, H.; Soto-Gutierrez, A.; Navarro-Alvarez, N.; Nahmias, Y.; Goldwasser, Y.; Kitagawa, Y.; Tilles, A.W.; Tompkins, R.G.; Parekkadan, B.; Yarmush, M.L. Reactive bone marrow stromal cells attenuate systemic inflammation via sTNFR1. Mol. Ther. J. Am. Soc. Gene Ther. 2010, 18, 1857-1864. [CrossRef]

116. Pradier, A.; Passweg, J.; Villard, J.; Kindler, V. Human bone marrow stromal cells and skin fibroblasts inhibit natural killer cell proliferation and cytotoxic activity. Cell Transplant. 2011, 20, 681-691. [CrossRef]

117. Kronsteiner, B.; Peterbauer-Scherb, A.; Grillari-Voglauer, R.; Redl, H.; Gabriel, C.; van Griensven, M.; Wolbank, S. Human mesenchymal stem cells and renal tubular epithelial cells differentially influence monocyte-derived dendritic cell differentiation and maturation. Cell. Immunol. 2011, 267, 30-38. [CrossRef]

118. Noronha, N.C.; Mizukami, A.; Caliari-Oliveira, C.; Cominal, J.G.; Rocha, J.L.M.; Covas, D.T.; Swiech, K.; Malmegrim, K.C.R. Priming approaches to improve the efficacy of mesenchymal stromal cell-based therapies. Stem Cell Res. Ther. 2019, $10,131$. [CrossRef]

119. Sivanathan, K.N.; Rojas-Canales, D.M.; Hope, C.M.; Krishnan, R.; Carroll, R.P.; Gronthos, S.; Grey, S.T.; Coates, P.T. Interleukin17A-Induced Human Mesenchymal Stem Cells Are Superior Modulators of Immunological Function. Stem Cells 2015, 33, 2850-2863. [CrossRef]

120. Torres Crigna, A.; Uhlig, S.; Elvers-Hornung, S.; Kluter, H.; Bieback, K. Human Adipose Tissue-Derived Stromal Cells Suppress Human, but Not Murine Lymphocyte Proliferation, via Indoleamine 2,3-Dioxygenase Activity. Cells 2020, 9, 2419. [CrossRef]

121. de Witte, S.F.; Franquesa, M.; Baan, C.C.; Hoogduijn, M.J. Toward Development of iMesenchymal Stem Cells for Immunomodulatory Therapy. Front. Immunol. 2015, 6, 648. [CrossRef] [PubMed]

122. Sivanathan, K.N.; Rojas-Canales, D.; Grey, S.T.; Gronthos, S.; Coates, P.T. Transcriptome Profiling of IL-17A Preactivated Mesenchymal Stem Cells: A Comparative Study to Unmodified and IFN-gamma Modified Mesenchymal Stem Cells. Stem Cells Int. 2017, 2017, 1025820. [CrossRef] [PubMed] 
123. English, K.; Barry, F.P.; Field-Corbett, C.P.; Mahon, B.P. IFN-gamma and TNF-alpha differentially regulate immunomodulation by murine mesenchymal stem cells. Immunol. Lett. 2007, 110, 91-100. [CrossRef] [PubMed]

124. Lin, T.; Pajarinen, J.; Nabeshima, A.; Lu, L.; Nathan, K.; Jamsen, E.; Yao, Z.; Goodman, S.B. Preconditioning of murine mesenchymal stem cells synergistically enhanced immunomodulation and osteogenesis. Stem Cell Res. Ther. 2017, 8, 277. [CrossRef] [PubMed]

125. Philipp, D.; Suhr, L.; Wahlers, T.; Choi, Y.H.; Paunel-Gorgulu, A. Preconditioning of bone marrow-derived mesenchymal stem cells highly strengthens their potential to promote IL-6-dependent M2b polarization. Stem Cell Res. Ther. 2018, 9, 286. [CrossRef]

126. Yao, M.; Cui, B.; Zhang, W.; Ma, W.; Zhao, G.; Xing, L. Exosomal miR-21 secreted by IL-1beta-primed-mesenchymal stem cells induces macrophage M2 polarization and ameliorates sepsis. Life Sci. 2020, 264, 118658. [CrossRef]

127. Song, Y.; Dou, H.; Li, X.; Zhao, X.; Li, Y.; Liu, D.; Ji, J.; Liu, F.; Ding, L.; Ni, Y.; et al. Exosomal miR-146a Contributes to the Enhanced Therapeutic Efficacy of Interleukin-1beta-Primed Mesenchymal Stem Cells Against Sepsis. Stem Cells 2017, 35, 1208-1221. [CrossRef]

128. Zimmermann, J.A.; Hettiaratchi, M.H.; McDevitt, T.C. Enhanced Immunosuppression of T Cells by Sustained Presentation of Bioactive Interferon-gamma Within Three-Dimensional Mesenchymal Stem Cell Constructs. Stem Cells Transl. Med. 2017, 6, 223-237. [CrossRef]

129. Chen, P.M.; Liu, K.J.; Hsu, P.J.; Wei, C.F.; Bai, C.H.; Ho, L.J.; Sytwu, H.K.; Yen, B.L. Induction of immunomodulatory monocytes by human mesenchymal stem cell-derived hepatocyte growth factor through ERK1/2. J. Leukoc. Biol. 2014, 96, 295-303. [CrossRef]

130. Cheng, H.; Wang, Z.; Fu, L.; Xu, T. Macrophage Polarization in the Development and Progression of Ovarian Cancers: An Overview. Front. Oncol. 2019, 9, 421. [CrossRef]

131. Nemeth, K.; Leelahavanichkul, A.; Yuen, P.S.; Mayer, B.; Parmelee, A.; Doi, K.; Robey, P.G.; Leelahavanichkul, K.; Koller, B.H.; Brown, J.M.; et al. Bone marrow stromal cells attenuate sepsis via prostaglandin E(2)-dependent reprogramming of host macrophages to increase their interleukin-10 production. Nat. Med. 2009, 15, 42-49. [CrossRef] [PubMed]

132. Mias, C.; Lairez, O.; Trouche, E.; Roncalli, J.; Calise, D.; Seguelas, M.H.; Ordener, C.; Piercecchi-Marti, M.D.; Auge, N.; Salvayre, A.N.; et al. Mesenchymal stem cells promote matrix metalloproteinase secretion by cardiac fibroblasts and reduce cardiac ventricular fibrosis after myocardial infarction. Stem Cells 2009, 27, 2734-2743. [CrossRef] [PubMed]

133. Jin, L.; Zhang, J.; Deng, Z.; Liu, J.; Han, W.; Chen, G.; Si, Y.; Ye, P. Mesenchymal stem cells ameliorate myocardial fibrosis in diabetic cardiomyopathy via the secretion of prostaglandin E2. Stem Cell Res. Ther. 2020, 11, 122. [CrossRef] [PubMed]

134. Prasanna, S.J.; Gopalakrishnan, D.; Shankar, S.R.; Vasandan, A.B. Pro-inflammatory cytokines, IFNgamma and TNFalpha, influence immune properties of human bone marrow and Wharton jelly mesenchymal stem cells differentially. PLoS ONE 2010, 5, e9016. [CrossRef]

135. Follin, B.; Juhl, M.; Cohen, S.; Pedersen, A.E.; Kastrup, J.; Ekblond, A. Increased Paracrine Immunomodulatory Potential of Mesenchymal Stromal Cells in Three-Dimensional Culture. Tissue Eng. Part Rev. 2016, 22, 322-329. [CrossRef]

136. Cerrada, I.; Ruiz-Sauri, A.; Carrero, R.; Trigueros, C.; Dorronsoro, A.; Sanchez-Puelles, J.M.; Diez-Juan, A.; Montero, J.A.; Sepulveda, P. Hypoxia-inducible factor 1 alpha contributes to cardiac healing in mesenchymal stem cells-mediated cardiac repair. Stem Cells Dev. 2013, 22, 501-511. [CrossRef]

137. Kojima, Y.; Tsuchiya, A.; Ogawa, M.; Nojiri, S.; Takeuchi, S.; Watanabe, T.; Nakajima, K.; Hara, Y.; Yamashita, J.; Kikuta, J.; et al. Mesenchymal stem cells cultured under hypoxic conditions had a greater therapeutic effect on mice with liver cirrhosis compared to those cultured under normal oxygen conditions. Regen. Ther. 2019, 11, 269-281. [CrossRef]

138. Fabregat, I.; Caballero-Diaz, D. Transforming Growth Factor-beta-Induced Cell Plasticity in Liver Fibrosis and Hepatocarcinogenesis. Front. Oncol. 2018, 8, 357. [CrossRef]

139. Fadok, V.A.; Bratton, D.L.; Konowal, A.; Freed, P.W.; Westcott, J.Y.; Henson, P.M. Macrophages that have ingested apoptotic cells in vitro inhibit proinflammatory cytokine production through autocrine/paracrine mechanisms involving TGF-beta, PGE2, and PAF. J. Clin. Investig. 1998, 101, 890-898. [CrossRef]

140. Wynn, T.A.; Barron, L. Macrophages: Master regulators of inflammation and fibrosis. Semin. Liver Dis. 2010, 30, $245-257$. [CrossRef]

141. Damania, A.; Jaiman, D.; Teotia, A.K.; Kumar, A. Mesenchymal stromal cell-derived exosome-rich fractionated secretome confers a hepatoprotective effect in liver injury. Stem Cell Res. Ther. 2018, 9, 31. [CrossRef] [PubMed]

142. Sharma, R.R.; Pollock, K.; Hubel, A.; McKenna, D. Mesenchymal stem or stromal cells: A review of clinical applications and manufacturing practices. Transfusion 2014, 54, 1418-1437. [CrossRef]

143. Wang, S.; Li, L.; Liu, T.; Jiang, W.; Hu, X. miR-19a/19b-loaded exosomes in combination with mesenchymal stem cell transplantation in a preclinical model of myocardial infarction. Regen. Med. 2020, 15, 1749-1759. [CrossRef] [PubMed]

144. Chen, C.; Chen, T.; Li, Y.; Xu, Y. miR-19a/19b improves the therapeutic potential of mesenchymal stem cells in a mouse model of myocardial infarction. Gene Ther. 2020. [CrossRef]

145. Zhu, M.; Liu, X.; Li, W.; Wang, L. Exosomes derived from mmu_circ_0000623-modified ADSCs prevent liver fibrosis via activating autophagy. Hum. Exp. Toxicol. 2020, 39, 1619-1627. [CrossRef] [PubMed]

146. Guo, Y.; Chen, B.; Chen, L.J.; Zhang, C.F.; Xiang, C. Current status and future prospects of mesenchymal stem cell therapy for liver fibrosis. J. Zhejiang Univ. Sci. B 2016, 17, 831-841. [CrossRef]

147. Matsuda, Y.; Matsumoto, K.; Yamada, A.; Ichida, T.; Asakura, H.; Komoriya, Y.; Nishiyama, E.; Nakamura, T. Preventive and therapeutic effects in rats of hepatocyte growth factor infusion on liver fibrosis/cirrhosis. Hepatology 1997, 26, 81-89. [CrossRef] 
148. Matsuno, Y.; Iwata, H.; Umeda, Y.; Takagi, H.; Mori, Y.; Kosugi, A.; Matsumoto, K.; Nakamura, T.; Hirose, H. Hepatocyte growth factor gene transfer into the liver via the portal vein using electroporation attenuates rat liver cirrhosis. Gene Ther. 2003, 10, 1559-1566. [CrossRef]

149. Ueki, T.; Kaneda, Y.; Tsutsui, H.; Nakanishi, K.; Sawa, Y.; Morishita, R.; Matsumoto, K.; Nakamura, T.; Takahashi, H.; Okamoto, E.; et al. Hepatocyte growth factor gene therapy of liver cirrhosis in rats. Nat. Med. 1999, 5, 226-230. [CrossRef]

150. Yasuda, H.; Imai, E.; Shiota, A.; Fujise, N.; Morinaga, T.; Higashio, K. Antifibrogenic effect of a deletion variant of hepatocyte growth factor on liver fibrosis in rats. Hepatology 1996, 24, 636-642. [CrossRef]

151. Kim, M.D.; Kim, S.S.; Cha, H.Y.; Jang, S.H.; Chang, D.Y.; Kim, W.; Suh-Kim, H.; Lee, J.H. Therapeutic effect of hepatocyte growth factor-secreting mesenchymal stem cells in a rat model of liver fibrosis. Exp. Mol. Med. 2014, 46, e110. [CrossRef] [PubMed]

152. Park, B.W.; Jung, S.H.; Das, S.; Lee, S.M.; Park, J.H.; Kim, H.; Hwang, J.W.; Lee, S.; Kim, H.J.; Kim, H.Y.; et al. In vivo priming of human mesenchymal stem cells with hepatocyte growth factor-engineered mesenchymal stem cells promotes therapeutic potential for cardiac repair. Sci. Adv. 2020, 6, eaay6994. [CrossRef] [PubMed]

153. Wang, H.; Yang, Y.F.; Zhao, L.; Xiao, F.J.; Zhang, Q.W.; Wen, M.L.; Wu, C.T.; Peng, R.Y.; Wang, L.S. Hepatocyte growth factor gene-modified mesenchymal stem cells reduce radiation-induced lung injury. Hum. Gene Ther. 2013, 24, 343-353. [CrossRef] [PubMed]

154. Xue, J.; Li, X.; Lu, Y.; Gan, L.; Zhou, L.; Wang, Y.; Lan, J.; Liu, S.; Sun, L.; Jia, L.; et al. Gene-modified mesenchymal stem cells protect against radiation-induced lung injury. Mol. Ther. J. Am. Soc. Gene Ther. 2013, 21, 456-465. [CrossRef] [PubMed] 